\title{
Magnetic Particles: Their Applications from Sample Preparations to Biosensing Platforms
}

\author{
Seong-Eun Kim ${ }^{1}$, My Van Tieu ${ }^{2} \mathbb{D}$, Sei Young Hwang ${ }^{2}$ and Min-Ho Lee ${ }^{2, * \mathbb{C}}$ \\ 1 Human IT Convergence Research Center, Korea Electronics Technology Institute, Gyeonggi-do 13509, Korea; \\ sekim@keti.re.kr \\ 2 School of Integrative Engineering, Chung-Ang University, 84 Heukseok-ro, Seoul 06974, Korea; \\ tmvantp0113@gmail.com (M.V.T.); forsylife@gmail.com (S.Y.H.) \\ * Correspondence: mhlee7@cau.ac.kr; Tel.: +82-2-820-5503; Fax: +82-2-814-2651
}

Received: 27 December 2019; Accepted: 10 March 2020; Published: 13 March 2020

\begin{abstract}
The growing interest in magnetic materials as a universal tool has been shown by an increasing number of scientific publications regarding magnetic materials and its various applications. Substantial progress has been recently made on the synthesis of magnetic iron oxide particles in terms of size, chemical composition, and surface chemistry. In addition, surface layers of polymers, silica, biomolecules, etc., on magnetic particles, can be modified to obtain affinity to target molecules. The developed magnetic iron oxide particles have been significantly utilized for diagnostic applications, such as sample preparations and biosensing platforms, leading to the selectivity and sensitivity against target molecules and the ease of use in the sensing systems. For the process of sample preparations, the magnetic particles do assist in target isolation from biological environments, having non-specific molecules and undesired molecules. Moreover, the magnetic particles can be easily applied for various methods of biosensing devices, such as optical, electrochemical, and magnetic phenomena-based methods, and also any methods combined with microfluidic systems. Here we review the utilization of magnetic materials in the isolation/preconcentration of various molecules and cells, and their use in various techniques for diagnostic biosensors that may greatly contribute to future innovation in point-of-care and high-throughput automation systems.
\end{abstract}

Keywords: point-of-care; sample preparation; diagnostics; biosensor; magnetic nanoparticles

\section{Introduction}

Magnetic particles typically refer to the materials consisting of magnetite $\left(\mathrm{Fe}_{3} \mathrm{O}_{4}\right)$ or maghemite (gamma- $\mathrm{Fe}_{2} \mathrm{O}_{3}$ ) ranging from sub-nano to micro-meters in size which respond to an external magnetic field [1]. Due to their unique magnetic property, they have great potentials in a variety of biological applications in their bare form or coated with surface coating materials and functional groups chosen for specific uses [2-7]. Isolation and separation of specific target molecules, including small drugs, deoxyribonucleic acid (DNA), proteins, and cells from biological media are necessary for bioscience and biomedical applications. However, biological environments known as highly complex matrixes (i.e., serum, urine, saliva, etc.) and also typical separation processes, e.g., the silica-based column method, are required to have a time-consuming procedure, and even traditional ones, e.g., the phenol/alcohol precipitation method, require toxic reagents for the extraction of DNA/(ribonucleic acid)RNA, proteins, etc. [8]. In recent developments, magnetic particles can improve the efficiency of target molecule separations without harmful reagents. Due to different compositions, sizes and magnetic properties, magnetic nanoparticles (MNPs) can be used in a variety of instruments and formats for biosensing with an enhancement of sensitivity and the stability [9-11]. Thus, many types of biosensors have been using surface-functionalized magnetic particles to recognize specific molecular targets with 
high sensitivity and selectivity. In the field of biomedical applications, a wide spectrum of advanced materials, including micro and nanoparticles, have been developed for sample preparation and biosensing platforms [12-14]. The use of magnetic particles has allowed the biomedical processes to be quick, simple, robust, and high-throughput systems. In this review, a number of cases of magnetic materials applied in isolation/pre-concentration of various target molecules and their use in recent biosensing platforms for biomedical applications will be given. It has been highly anticipated that these current developments in magnetic particle may contribute to future innovation in point-of-care and high-throughput systems to increase the chance of successful diagnostics and clinical treatments.

\section{Sample Preparations Using Magnetic Particles}

Magnetic particles are considered interesting materials that are widely used in many applications, such as separation, diagnostics, and therapeutics. Magnetic nanoparticles can easily be separated from complex matrices such as biological samples by using an external magnetic field. Thus, traditional separation processes are not required, such as filtration or centrifugation. Magnetic solid-phase extraction (MSPE) was proposed for the facile and fast sample preparation processes. The magnetic materials are generally directly dispersed in the sample solutions for the rapid extraction process because they can be readily recovered by a magnet. Typically, the MSPE material is composed of a magnetic core and the functionalized outer surface of the same particle to be collected by using a magnet and for the extraction of various target compounds from biological samples (i.e., serum, urine, saliva, etc.), respectively.

\subsection{MP-Based Drug Extraction from Biological Samples}

MSPE for drug molecule extraction from biological samples (blood plasma, urine, etc.) is one of the crucial application areas of magnetic nanoparticles. Carbon coated magnetic $\mathrm{Fe}_{3} \mathrm{O}_{4}$ nanoparticles were used for extracting pharmaceutical compounds, including carvedilol, losartan, and amlodipine besylate, from plasma samples [15]. Magnetic nanocomposites composed of $\mathrm{Fe}_{3} \mathrm{O}_{4}$ nanoparticles and polyaniline were developed and successfully separated benxodiazepine drugs, including nitrazepam and lorazepam, from human plasma and urine samples [16]. Multiwalled carbon nanotube coated $\mathrm{Fe}_{3} \mathrm{O}_{4}$ nanoparticles used for the efficient extraction of brucine (a neurotoxic alkaloid existing in the Nux-vomica tree) from human urine samples were also reported [17]. For the selective extraction of seven estrogens from human urine samples, magnetic $\mathrm{Fe}_{3} \mathrm{O}_{4}$ nanoparticles having a layer composed of 1,3,5-triformylbenzene (Tb) and benzidine $(\mathrm{Bd})\left(\mathrm{Fe}_{3} \mathrm{O}_{4} @ \mathrm{TbBd}\right)$ were prepared and successfully applied [18]. Organic dendrimer-modified magnetic $\mathrm{Fe}_{3} \mathrm{O}_{4}$ nanoparticles for the extraction of rosuvastatin from human urine and blood plasma were reported [19]. The magnetic $\mathrm{Fe}_{3} \mathrm{O}_{4}$ nanoparticles were first synthesized by using $\mathrm{FeCl}_{2}$ and $\mathrm{FeCl}_{3}$. The surface of the synthesized magnetic $\mathrm{Fe}_{3} \mathrm{O}_{4}$ nanoparticles was conjugated with organic dendrimers containing ethylene diamine and methyl methacrylate, and then applied for efficient separation, achieving $61 \mathrm{mg} \mathrm{g}^{-1}$. In addition, magnetic nanoparticles having a molecularly imprinted polymeric (MIP) layer were successfully developed and utilized for the selective separation of 9-hydroxyrisperidone and risperidone from human urine samples [20]. Polydopamine(pDA)-coated magnetic $\mathrm{Fe}_{3} \mathrm{O}_{4}$ nanoparticles modified with multi-walled carbon nanotubes (MWCNTs) were prepared. Owing to the pDA, it results in the formation of a continuous coating layer on the substrate magnetic material via strong binding affinity of catechol functional groups. The prepared magnetic nanoparticles were successfully used for the extraction of antiepileptic drugs, including phenytoin, oxcarbazepine, and carbamazepine from human urine, plasma, and cerebrospinal fluid samples [21].

\subsection{MP-Based DNA/RNA Extraction from Biological Samples}

Magnetic particles have significant advantages in both ease of use and high purity when isolating nucleated cells and nucleotides directly from biological samples. Although the extracted genomic DNA (gDNA) are easily contaminated by various known enzyme inhibitors (phenol, urea, and salts) originating from the traditional organic extraction and/or biological samples, this approach concentrates 
and extracts gDNA and eliminates the influence of physiological metabolites from the biological samples that would otherwise inhibit enzyme activities for polymerase chain reaction (PCR). Shan et al. used carboxylated magnetic nanoparticles (CMNPs) to develop a PCR-ready gDNA extraction from urine and blood samples. CMNPs were first used for cell extractions and then absorbed gDNA from the lysates. Relative to traditional methods, the present procedure required less handling, no hazardous reagents (e.g., chloroform), and could be carried out in single microcentrifuge tube within $30 \mathrm{~min}$. These methods, while simple, rapid, sensitive, and environmentally friendly, are suitable for routine laboratory use, but also hold promise for the construction of automated urine extraction systems for various diagnostic purposes [22-24].

\subsection{MP-Based Protein/Peptide Isolation from Biological Samples}

The use of magnetic particles is highly convenient and rapid for separations of proteins and peptide. Magnetic beads exhibit low non-specific binding of non-target molecules included in different samples. For certain samples, preclearing may be required to remove molecules having highly non-specific binding affinity. First, the sample can be mixed with magnetic nanoparticles not coated with the affinity ligand. For the case of immunomagnetic separation, magnetic nanoparticles have been coated with secondary antibody or with irrelevant antibodies. In addition, the non-specific binding can also be reduced by adding a non-ionic detergent either in the sample or in the washing buffers during the isolation of the target. In general, magnetic particles for protein/peptide separation can be used in two different methods. In the direct method, an appropriate affinity ligand is directly coupled to the magnetic particles exhibiting the affinity towards target compounds. These particles are added to the sample and target compounds then bind to them. In the indirect method, the free affinity ligand (in most cases an appropriate antibody) is added to the solution to enable the interaction with the target compound. The resulting complex is then captured by appropriate magnetic particles. In both methods, magnetic particles with isolated target compounds are magnetically separated, and then several washing steps are performed to the remove majority of contaminating compounds and particles. The target compounds are then usually eluted. In most cases, bound protein/peptide can be added to standard elution methods, such as the change of $\mathrm{pH}$, change of ionic strength, and use of polarity reducing agent (e.g., dioxane or ethyleneglycol). Affinity elution (e.g., elution of glycoproteins from lectin coated magnetic beads by the addition of free sugar) may be both efficient and gentle. The following examples are for the protein/peptide magnetic separations (Table 1).

Table 1. Examples of proteins/peptides purified by magnetic techniques.

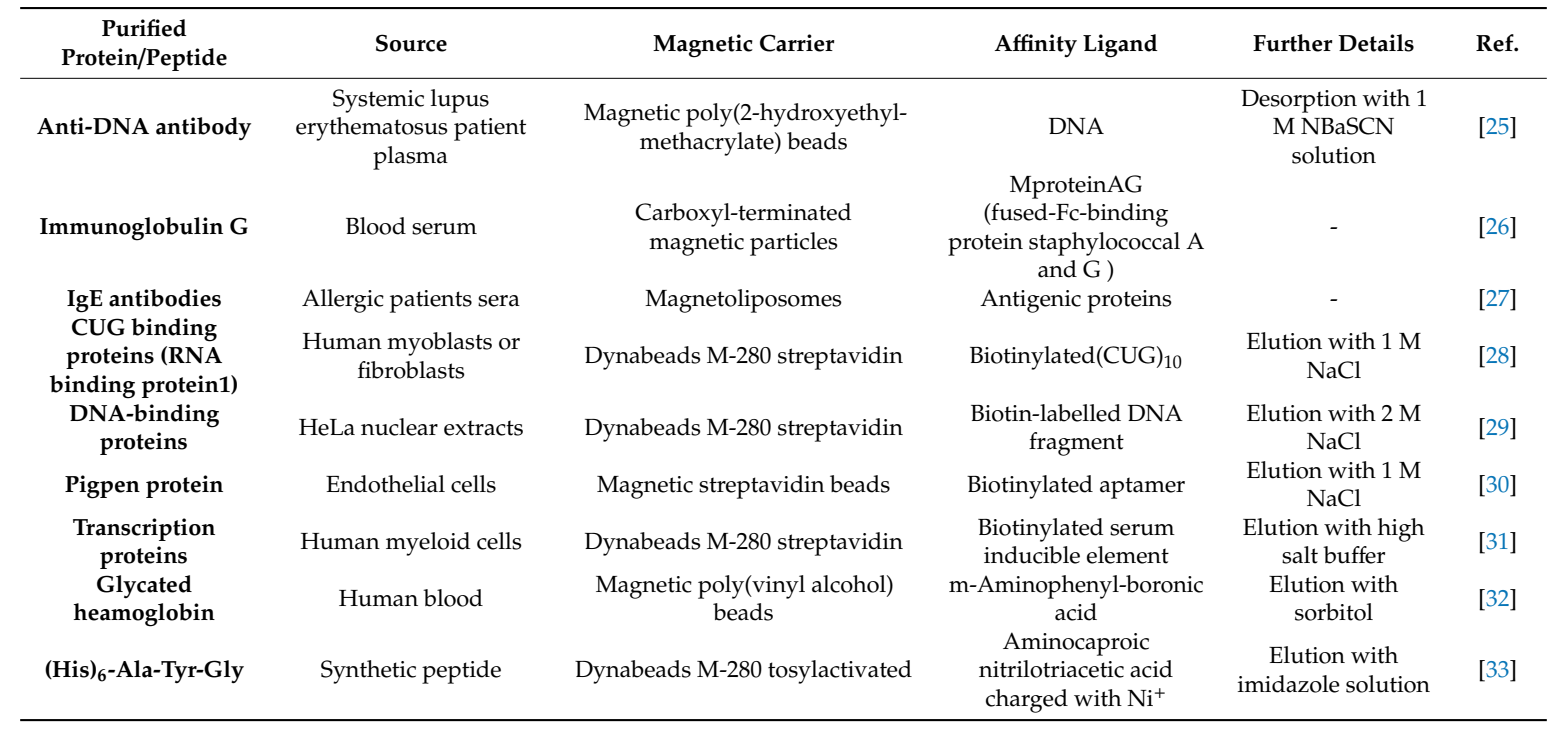




\section{Biosensing Devices Using Magnetic Particles}

In this section, we summarized recent studies of biosensing devices that apply magnetic materials. They have advantageous functional capabilities, such as their magnetic property, low background noise, good dispersions, and highly biocompatible surfaces with regard to the immobilized recognizable bioreceptors [34-37]. With the continuing multidisciplinary development of magnetic-particle-based biosensing techniques, these efforts have found the way for modern biological devices for on-site or high-throughput purposes by replacing sophisticated monitoring biomedical devices. Of the varied biosensing devices available, we have paid attention to two main biosensing devices; i.e., optical sensing devices and electrochemical sensing devices with the integration of magnetic material for sensing biological targets. As illustrated in Figure 1, we have paid much attention to smartphones and other mobile devices integrated with detection in paper-based analytical devices or lateral-flow immunochromatographic assays (LFIA) — and the interdigitated array microelectrode, screen-printed electrode, and microfluidic devices too-providing useful insights on point-of-care healthcare devices.

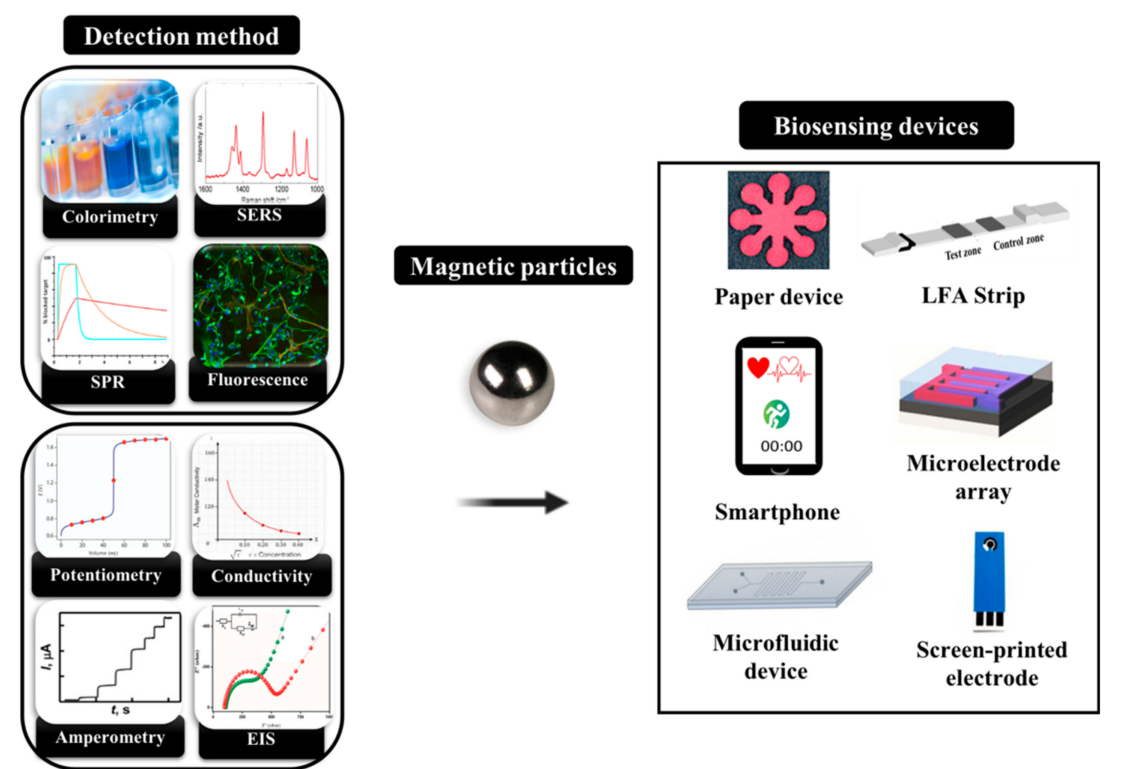

Figure 1. Schematic representation of the detection method based on either optical or electrochemical techniques combined with magnetic materials for biosensing.

\subsection{Optical Biosensing Devices}

Optical biosensing devices have been developed to offer a simple and rapid approach for sensing biological analytes. This method has been classified into, mainly, four techniques: colorimetric, fluorescent, surface plasmon resonance (SPR), and surface-enhanced Raman scattering methods, which are combined with magnetic particles in integrated devices; these were reported in proof-of-concept studies. Here, we discuss how the magnetic particles can be adapted to the optical sensing systems.

\subsubsection{Colorimetric Biosensing Devices}

Colorimetric biosensing techniques are to transform the detection of biological elements into measurable color changes. Additionally, they are inexpensive and only require simple detection equipment $[36,37]$. For various colorimetric devices for analysis, lateral flow tests (LFA) and paper devices are the main methods which are commonly associated with enzyme-linked immunosorbent assay (ELISA) to identify targets [38]. As mentioned earlier, these devices combined with MNPs have benefits such as sensitivity, specificity, speed, and inexpensive platforms [39]. Moreover, due to the small testing sample volume, vulnerable individuals being exposed to dangerous chemicals is not an issue. Lastly, colorimetric tests are primarily tested with digital images, leading to an objective 
automated analysis by smartphone or camera $[40,41]$. Table 2 summarizes magnetic-materials-based colorimetric devices developed and employed for the quantification of biological targets.

Table 2. Summary of the strategies used for magnetic-biomaterials-based colorimetric devices.

\begin{tabular}{|c|c|c|c|c|c|c|c|}
\hline $\begin{array}{c}\text { Types of } \\
\text { Detection } \\
\text { Platform }\end{array}$ & Target & $\begin{array}{l}\text { Magnetic } \\
\text { Biomaterial }\end{array}$ & Linear Range & $\begin{array}{l}\text { Limit of } \\
\text { Detection } \\
\text { (LOD) }\end{array}$ & Advantageousness & $\begin{array}{l}\text { Detection } \\
\text { Time }\end{array}$ & Ref. \\
\hline $\begin{array}{l}\text { Paper-based } \\
\text { analytical device } \\
\text { (PAD) }\end{array}$ & $\begin{array}{c}\text { Bacteria } \\
\text { (S. typhimurium) }\end{array}$ & Magnetic beads & $\begin{array}{l}10^{2} \text { to } 10^{8} \text { colony } \\
\text { forming unit (CFU) } \\
\mathrm{mL}^{-1}\end{array}$ & $10^{2} \mathrm{CFU} \mathrm{mL} \mathrm{m}^{-1}$ & $\begin{array}{l}\text { Simple, rapid and } \\
\text { sensitive without } \\
\text { pre-enrichment } \\
\text { sample }\end{array}$ & $90 \mathrm{~min}$ & [42] \\
\hline $\begin{array}{l}\text { Lateral-flow } \\
\text { immunochro- } \\
\text { matographic } \\
\text { assays (LFIA) }\end{array}$ & Antigen (hCG) & $\begin{array}{c}\mathrm{Fe}_{3} \mathrm{O}_{4}-\mathrm{Pt} / \\
\text { core-shell } \\
\text { nanoparticles }\end{array}$ & 0 to $1 \mathrm{ng} \mathrm{mL}-1$ & $\begin{array}{c}0.039 \\
\text { ng } \mathrm{mL}^{-1}\end{array}$ & $\begin{array}{l}\text { Sensitive more than } \\
\text { conventional } \\
\text { Au-LFIA }\end{array}$ & - & [43] \\
\hline $\begin{array}{l}\text { Lateral-flow } \\
\text { immunochro- } \\
\text { matographic } \\
\text { assays (LFIA) }\end{array}$ & $\begin{array}{c}\text { Bacteria } \\
\text { (B. anthracis) }\end{array}$ & $\begin{array}{c}\text { Super-paramagnetic } \\
\text { particles }\end{array}$ & $\begin{array}{c}2.0 \times 10^{3} \text { to } 1.0 \times 10^{6} \\
\quad \text { CFU mL }\end{array}$ & $\begin{array}{c}7.0 \times 10^{3} \\
\mathrm{CFU} \mathrm{mL} \mathrm{mL}^{-1}\end{array}$ & $\begin{array}{l}\text { Sensitive, specificity, } \\
\text { cost and ease of } \\
\text { operation }\end{array}$ & $20 \mathrm{~min}$ & [44] \\
\hline $\begin{array}{l}\text { Paper-based } \\
\text { MNP-gold } \\
\text { sensing assays }\end{array}$ & $\begin{array}{c}\text { Bacteria } \\
\text { (Escherichia coli } \\
\text { O157:H7) }\end{array}$ & $\begin{array}{c}\text { Magnetic } \\
\text { nanoparticles }\end{array}$ & $\begin{array}{l}1.21 \times 10^{1} \text { to } 1.21 \times \\
10^{6} \mathrm{CFU} \mathrm{mL}^{-1}\end{array}$ & $12 \mathrm{CFU} \mathrm{mL}^{-1}$ & $\begin{array}{l}\text { Simple to perform, } \\
\text { low cost, rapid } \\
\text { without } \\
\text { pre-enrichment } \\
\text { sample }\end{array}$ & $\begin{array}{l}\text { Less than } \\
30 \mathrm{~s}\end{array}$ & [45] \\
\hline $\begin{array}{l}\text { Lateral-flow } \\
\text { immunochro- } \\
\text { matographic } \\
\text { assays (LFIA) }\end{array}$ & Antigen (CFB) & $\begin{array}{c}\text { Magnetized Carbon } \\
\text { Nanotube }\end{array}$ & 5 to $100 \mathrm{ng} \mathrm{mL}^{-1}$ & $5 \mathrm{ng} \mathrm{mL}^{-1}$ & $\begin{array}{c}\text { Rapid and } \\
\text { low-cost tool }\end{array}$ & $30 \mathrm{~min}$ & [47] \\
\hline $\begin{array}{l}\text { Peroxide strip } \\
\text { based assay } \\
\text { analyzed by } \\
\text { Smartphone }\end{array}$ & $\begin{array}{c}\text { Bacteria } \\
\text { (S. typhimurium) }\end{array}$ & $\begin{array}{l}\text { Immunomagnetic } \\
\text { nanoparticles }\end{array}$ & $\begin{array}{l}10^{1} \text { to } 10^{5} \\
\text { CFU mL }\end{array}$ & $\begin{array}{c}1.6 \times 10^{1} \\
\mathrm{CFU} \mathrm{mL}\end{array}$ & $\begin{array}{l}\text { Simple, portable and } \\
\text { low-cost method for } \\
\text { rapid detection }\end{array}$ & $45 \mathrm{~min}$ & [48] \\
\hline $\begin{array}{l}\text { Nucleic acid } \\
\text { lateral flow } \\
\text { (NALF) assay }\end{array}$ & $\begin{array}{l}\text { Nucleic acid } \\
\text { (L. monocytogenes) }\end{array}$ & $\begin{array}{l}\text { Immunomagnetic } \\
\text { nanoparticles }\end{array}$ & $\begin{array}{l}10^{0} \text { to } 10^{7} \\
\text { CFU mL }\end{array}$ & $\begin{array}{l}3.5 \times 10^{3} \\
\mathrm{CFU} \mathrm{mL}\end{array}$ & $\begin{array}{l}\text { Excellent viable } \\
\text { capability for viable } \\
\text { L. monocytogenes }\end{array}$ & $6 \mathrm{~h}$ & [49] \\
\hline
\end{tabular}

Recently, Russell et al. depicted a sensitive colorimetric assay for the detection sepsis biomarkers in whole blood on filter papers [50]. Biotinylated capture antibodies and avidin-labeled particles were used to remove non-specific interactions with target PCT. It was followed by the motion-to-color transduction process and further amplification via Janus nanoparticles. Finally, these color changes are then read and quantified by customized smartphone apps. The assay depicted high sensitivity (limit of detection (LOD) $=2 \mathrm{ng} \cdot \mathrm{mL}^{-1}$ ) in the dynamic linear range of $1-20 \mathrm{ng} \mathrm{mL}^{-1}$ within $13 \mathrm{~min}$ and potential application in whole blood without preparation. And another example is from Li's group, who published a rapid and effective method for a L. monocytogenes gene; it is a major infectious pathogen that threatens public health worldwide [51]. In this study, in the strong interaction between streptavidin and biotin, the immunomagnetic-streptavidin is effectively attached to L. monocytogenes cells for high molecular identification and catalytic activity. The genomic DNA of L. monocytogenes was extracted, and PCR was performed to create single-strand DNA amplifiers (ssDNA). Finally, through the nucleic acid lateral flow (NALF) biosensor, ssDNA amplifiers were detected by the naked eye. The LOD and the linear range for L. monocytogenes were $3.5 \times 10^{3}$ colony forming unit $(\mathrm{CFU}) \mathrm{mL}^{-1}$ and $10^{0}$ to $10^{7} \mathrm{CFU} \mathrm{mL} \mathrm{m}^{-1}$, respectively.

\subsubsection{Fluorescent Biosensing Devices}

Fluorescent biosensing devices are based on changes caused by analytes in the chemical and physical properties of fluorophores, including fluorescence intensity, lifetime, and anisotropy, in connection with the process of charge transfer or power transmission process [52,53]. In addition, it has been known as an effective method for multiple and highly sensitive detections of biological targets in molecular and clinical diagnosis to monitor disease progression and drug/therapy method response to diagnose images and image-guided surgery [54-57]. The use of magnetic particles enables the high washing efficiency of the target separation step to rapidly remove the unwanted components, resulting in the enhancement of the limit of detection. Based on those advantages, widely used 
fluorescence-based technologies for multiple/highly sensitive detections using the magnetic beads, such as Luminex xMAP [58-61], magnetic modulation biosensing (MMB) [62], Quanterix Simoa [63,64] and magnetically-modulated optical nanoprobes (MagMOONs) [65,66], have emerged. A recent study by Wang et al. pointed out a microfluidic biosensing device modification platform for Salmonella typhimurium measurement using fluorescent labeling and video processing on smartphones. Magnetic nanoparticles (MNPs) were modified with monoclonal antibodies against Salmonella typhimurium and then reacted with modified fluorescence microscopy (FMS) with polyclonal antibodies against Salmonella typhimurium to form a FMS-Salmonella complex. The structure of a smartphone-based fluorescent microscope system has been used with LED light sources to excite fluorescence to track the fluorescence points and the number of fluorescent bacteria calculated via real-time video processing within $2 \mathrm{~h}$. The detection limit (LOD) and linear range of Salmonella typhimurium were 58 CFU $\mathrm{mL}^{-1}$ and $1.4 \times 10^{2}$ to $1.4 \times 10^{6} \mathrm{CFU} \mathrm{mL} \mathrm{m}^{-1}$, respectively. The existence of Listeri monocytogenes, Escherichia coli O157: H7, and Vibrio parahaemolyticus in samples did not interfere with the detection of Salmonella typhimurium [67].

Other fluorescence methods to detect biological targets include the use of composite materials in which magnetic nanoparticles serve as the main material to facilitate higher detection capacity. To perform this method, several studies have tried to incorporate magnetic nanoparticles known to be capable of separating samples into a specific target of interest. In 2019, Zhang et al. developed fluorescent, magnetic, spore-based (spore@ $\mathrm{Fe}_{3} \mathrm{O}_{4} @ \mathrm{CDs}$ ) microrobots (FMSMs) for detecting toxins secreted by Clostridium difficile bacteria. Based on fluorescence property, the detection limit of this platform for Clostridium difficile was $2.13 \mathrm{ng} \mathrm{mL}^{-1}$ and the linear range was $0.38-17.80 \mathrm{ng} \mathrm{mL}^{-1}$ [68]. Therefore, owing to the selectivity of magnetic materials, this technique could be an effective method for various biological targets. Burg et al. also reported a cluster of magnetic particles based on fluorescence. Since the fluorescence is based on a cluster of magnetic beads with an active conic tip, a cluster of magnetic beads provides far greater fluorescent signals than single-particles. Human interleukin-8 was detected by fluorescent devices with a CMOS camera. The detection limit was $0.1 \mathrm{ng} \mathrm{L}^{-1}$ [69].

\subsubsection{Surface Plasmon Resonance Biosensing Devices}

Surface plasmon resonance (SPR) sensing techniques are based on photonic technology, electronics, and nanotechnology for label-free optical sensing technology, which allows for direct refractive index changes and real-time sensor surfaces, providing excellent sensitivity due to magnified electric fields. The rapid and widespread advancement of SPR technology has been done by using magnetic materials for the intensity of the sensitivity of reflected light at a specific angle called the resonant angle [70]. The changing color of the solution can be observed due to the change in reflectance angle or wavelength against time in SPR system [71,72]. Immunoassays with SPR devices have been successfully developed to detect the extracellular vesicles by using antibodies against CD81 [73]. Meanwhile, Reiner's group has utilized magnetic nanoparticles to develop the novel method of SPR combined with fluorescence, which resulted in 2.4-fold higher fluorescence than just an SPR detection channel only. In addition, a smartphone integrated compact system has been developed to detect different concentrations of antibodies under the $\mathrm{nM}$ range sensitivity, and the device has a resolution of $7.4 \times 10^{-5}$ refractive index unit (RIU) and weight of $40 \mathrm{~g}$ [74].

\subsubsection{Surface-Enhanced Raman Scattering Biosensing Devices}

Surface-enhanced Raman scattering (SERS) was founded in the 1970s by M. Fleischmannand et al. and can generate the spectral signatures of various biological analytes with its high sensitivity, specificity, and speed. Especially, SERS has intense penetration in complex biological sample matrices, such as in blood, and in pork samples [75-77]. For example, Xiong et al. reported the magnetic particle integrated microfluidic chip applied in SPR for a simple, rapid, and highly sensitive detection of multi cancer biomarkers (prostate specific antigen (PSA), alpha-fetoprotein (AFP), carcinoembryonic antigen (CEA), cancer antigen (CA) 125, and CA19-9) with the detection limit of PSA down to $0.2 \mathrm{pg} \mathrm{mL}^{-1}$ and bacterial 
species (E. coli O157: H7 and S. aureus) in $1 \mu \mathrm{L}$ of body fluids within 8 min (Figures 2 and 3) [78]. Zhang's group also demonstrated that $S$. typhimurium and $S$. aureus were detected by using aptamer probes and magnetic gold nanoparticles with enhanced Raman intensity under the SERS intensity at $1582 \mathrm{~cm}^{-1}$ in the range of $10^{2}-10^{7} \mathrm{CFU} \mathrm{mL}{ }^{-1}$. The limits of detection are $35 \mathrm{CFU} \mathrm{mL}{ }^{-1}$ for $\mathrm{S}$. aureus and $15 \mathrm{CFU} \mathrm{mL}^{-1}$ for S. typhimurium, respectively [79].

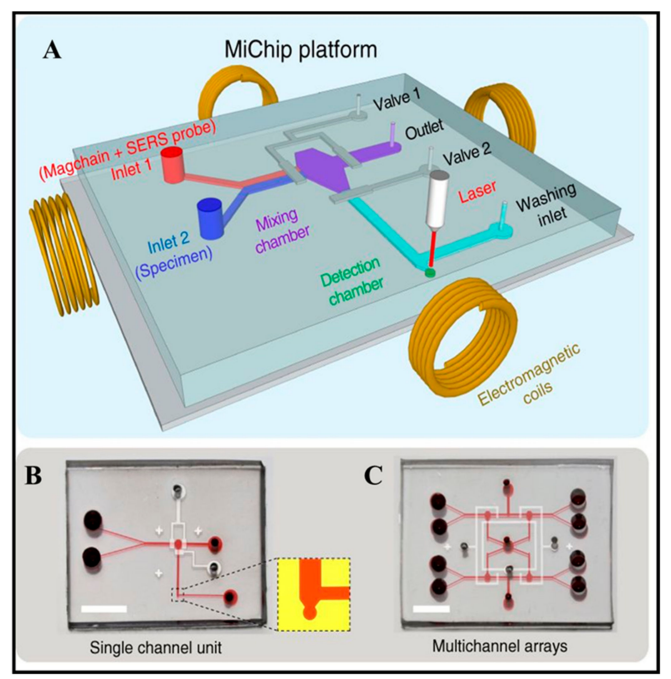

Figure 2. (A) Schematic illustration of the Magchain-integrated microchip (MiChip) assay platform: with (B) a single-channel unit and (C) multiple-channel arrays. Reproduced with permission from Xiong et al. [78].

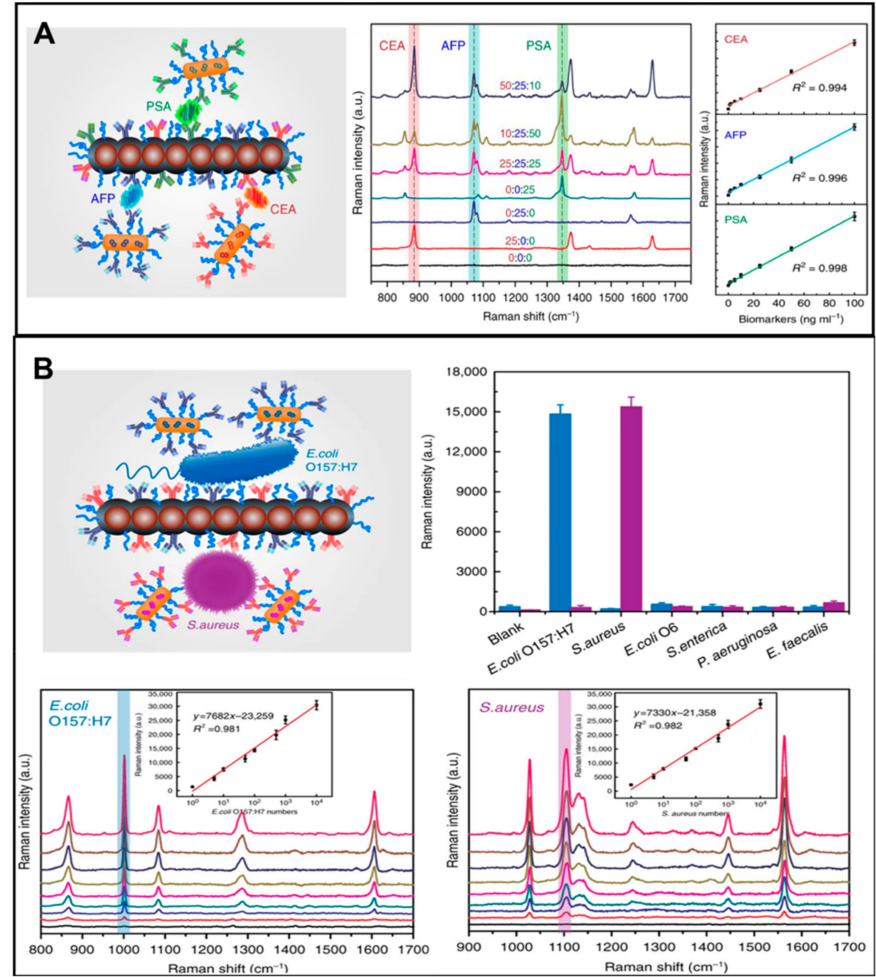

Figure 3. (A) Schematic, surface-enhanced Raman scattering (SERS) performance, and corresponding calibration curve with a mixture biomarkers (PSA, AFP, and CEA) at different concentrations from 0 to $100 \mathrm{ng} \mathrm{mL}^{-1}$; (B) schematic illustration of in-situ screening of detection of Escherichia coli O157:H7 and Staphylococcus aureus based on an MiChip assay with various concentrations (ranging from 0 to $104 \mathrm{CFU} \mu \mathrm{L}^{-1}$ ) and the results of saliva spiked samples in MiChip assay. Reproduced with permission from Xiong et al. [78]. 


\subsection{Electrochemical Biosensing Devices}

Electrochemical biosensing techniques require the understanding of the electrical properties of the detection method, such as its potential, current, capacitance, and impedance, to measure the electric current generated by the oxidation and reduction reactions of analytical targets. They are directly proportional to the concentrations of analyte in complex biological samples [80-82]. We can categorize the system of the electrochemical detection in biological samples into four techniques: potentiometric, conductometric, amperometric, and impedance biosensing devices (see Table 3). The development of electrochemical equipment, when combined with magnetic materials, has led to great potential for commercialization of biosensing devices.

\subsubsection{Potentiometric Biosensing Devices}

Potentiometry is an engaging instrument for many practical applications, because it allows the measurement of a wide spectrum of ions, and it applies mobile and reasonable price devices in numerous medical, industrial, and environmental tests $[36,83,84]$. The potentiometric transduction was first reported in 1969, in which an enzyme based sensor was used to detect urea [85]. It involves measuring the potential difference between the working and reference electrodes in order to generate different potentials from analysis when providing a constant voltage. In addition, there is no significant current flow between them [86]. Potentiometry usually has a large dynamic range due to the signal proportional to the logarithm of the ionic activity. In addition, they have a short response time, in the order of seconds, making them suitable for process control and enabling high sample throughput in flow analysis. Moreover, their small size, reasonably economical production values, low power expenditure, and portability, make them more proper for diverse purposes $[87,88]$. Liu et al. presented a specific single-cell detection device that is based on target cells that are conjugated with magnetic beads for the magnetic bead assay and two micro Coulter counters for potentiometric detection of human umbilical vein endothelial cells (HUVECs) [89]. The HUVECs' obviously have a much longer transit time distribution than the non-target rat adipose-derived stem cells (rASCs). They also reported that the various cell ratios $(2 \%, 5 \%, 10 \%, 30 \%$, and $50 \%)$ of HUVECs which can be detected in situ were accurately identified.

\subsubsection{Conductometric Biosensing Devices}

In this type of device, analytical information is obtained by measuring the electrical conductivity, due to the charge transmission of cations and anions under the action of an external electric field. In other words, the measurement is based on an electroanalytical method that involves measuring conductivity separated by a specific distance or environment, such as nanowires. Conductivity measurement is based on the alternating current (AC) power supply to apply across the electrode using an Ohmmeter. The main advantages of the instrumentation are that they do not require a reference electrode, are inexpensive, have the ability to minimize the direct electrical response, are fast, and are single-use biological devices [90-92]. In this study, urease based magnetic beads were modified with graphene oxide and nickel oxide to have conduction of interfacial electrons and high enzyme binding activity [93]. Upon the target outline in urea samples, the wireless measurement system and the microfluidic measurement system proceeded to separate testing assays. While using a microfluidic device, the developed biosensing device could measure urea at the sensitivity $5.582 \mathrm{mV}(\mathrm{mg} / \mathrm{dl})^{-1}$ with a linearity of 0.959 and high reliability.

\subsubsection{Amperometric Biosensing Devices}

Amperometry is the one of the most sensitive techniques to obtain high sensitivity in biosensor devices. This technique is based on the measurement of electric current as a function of the time due to the oxidation and reduction of an electrolyte in the biochemical reaction, largely depending on the concentration of the analyte of constant potential. Because most analytes (proteins) cannot 
essentially act as redox partners in the electrochemical reaction, electrons are also not transferred from the analyte to the working electrode or to the analyte from the electrode. To overcome that problem, a labeling electrochemical test is required for the electrochemical reaction of the analyte at the electrode surfaces. Horseradish peroxidase (HRP) and alkaline phosphatase (ALP) are the most commonly used as labels to catalyze the reaction of substrates to form electroactive products [94,95]. Bandodkar's group recently represented a rapid, sensitive, and reasonable price in printed electrochemical devices for the detection of $\mathrm{H}_{2} \mathrm{O}_{2}$ at self-healing electrodes [96]. As illustrated in Figure 4, a $\mathrm{Nd}_{2} \mathrm{Fe}_{14} \mathrm{~B}$ microparticle (NMP)-loaded graphitic inks were used to improve the self-healing ability with highly repeats recovery. It was followed by amperometric quantification of $\mathrm{H}_{2} \mathrm{O}_{2}$, with repeat five times for each $\mathrm{H}_{2} \mathrm{O}_{2}$ concentration at the same location. This assay produced a new self-healing notion, and the inherent application can also be applied in the wearable device based electrical circuits.

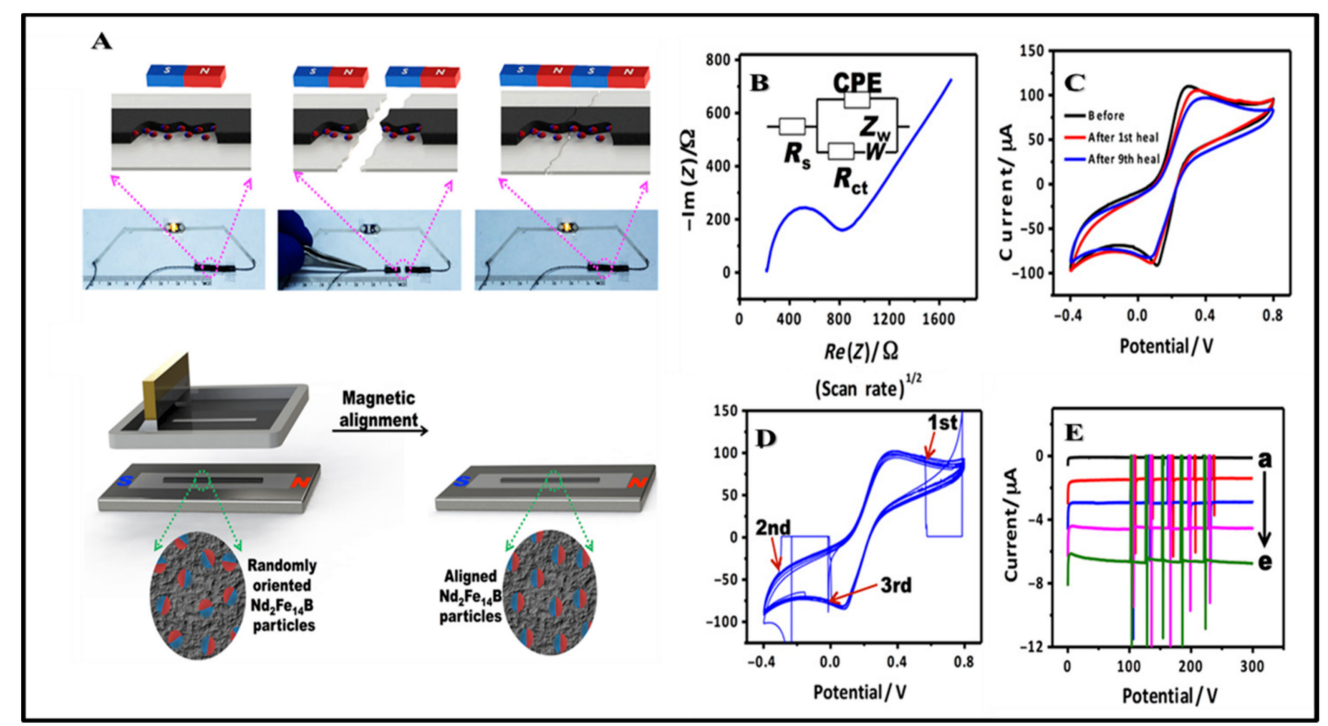

Figure 4. (A) Schematic diagram to illustrate the fabrication of self-healing principle and the manufacturing process; (B) Nyquist plot for self-healing printed electrodes; (C) cyclic voltammetry (CV) plots recorded for a self-healing trace; (D) real-time recovery of triple damage $3 \mathrm{~mm}$ wide; (E) amperometric response of the fabricated self-healing $\mathrm{H}_{2} \mathrm{O}_{2}$ in different concentrations from 0 to $20 \mathrm{mM}$ and under 1-mm-wide damage repetition. Reproduced with permission from [60].

\subsubsection{Impedimetric Biosensing Devices}

In electrochemical impedance spectroscopy (EIS), there are interference characteristics of surface-changing electrodes and mechanisms of charge transfer and ion transport in the electrolytic interface, which have recently become widespread tools for bioreceptors. This method is known as an oscilloscope scan with a frequency of electrical sweep of the immunoassay system, within $10 \mathrm{kHz}$ and $10 \mathrm{mHz}$, with these parameters being resistance (R), resistance transfer charge (Rct) between solution and electrode surface, Warburg element (Zw), and double-layer capacitance (Cdl) [97,98]. The sample impedance is calculated as the ratio of voltage to current with both amplitude and phase: a complex number. EIS may have the strongest advantage of lower concentration detection (nano unit and pico unit) and is capable of testing for unlabeled detection $[99,100]$. In one of the studies by Wang et al., thrombin was electrochemically tracked in biological samples in serum using a microfluidic system and magnetic separation functionalized with the detection of protein. The probe thrombin-aptamer was coated magnetic beads to capture and separate thrombin target. After the target was injected into the microfluidic flow cell, the values of impedance changed, owing to the fact that the concentration of thrombin is proportional to the charges on the thrombin surface. This microfluidic device submitted a notable, rapid, specific, and sensitive method, with a detection limit of $0.01 \mathrm{nM}$ and a linear range from $0.1 \mathrm{nM}$ to $10 \mathrm{nM}$ [101]. Another study was conducted by Kongsuphol's team to detect tumor necrosis 
factor (TNF- $\alpha$ ) by using a magnetic antibody biosensor-based biosensor platform [102]. Abundant protein sources are drained from the serum by using magnetic particles in combination with albumin and IgG antibodies. TNF- $\alpha$ is then captured by TNF- $\alpha$ antibodies conjugated with magnetic particles. The conjugated TNF- $\alpha$ was eluted from magnetic particles and measured using EIS technique which combined a structured gold microelectrode array (CSGM) to detect ultrasensitive $1 \mathrm{pg} \mathrm{mL}^{-1}$ with undiluted human serum and linearity from 1 to $1000 \mathrm{pg} \mathrm{mL}^{-1}$. Both published methods are designed to be sensitive, simple, and label-free platforms. As shown in Table 3, we summarized the strategies for electrochemical biosensor using magnetic particles.

Table 3. Summary of the strategies used for magnetic biomaterials based electrochemical biosensing devices.

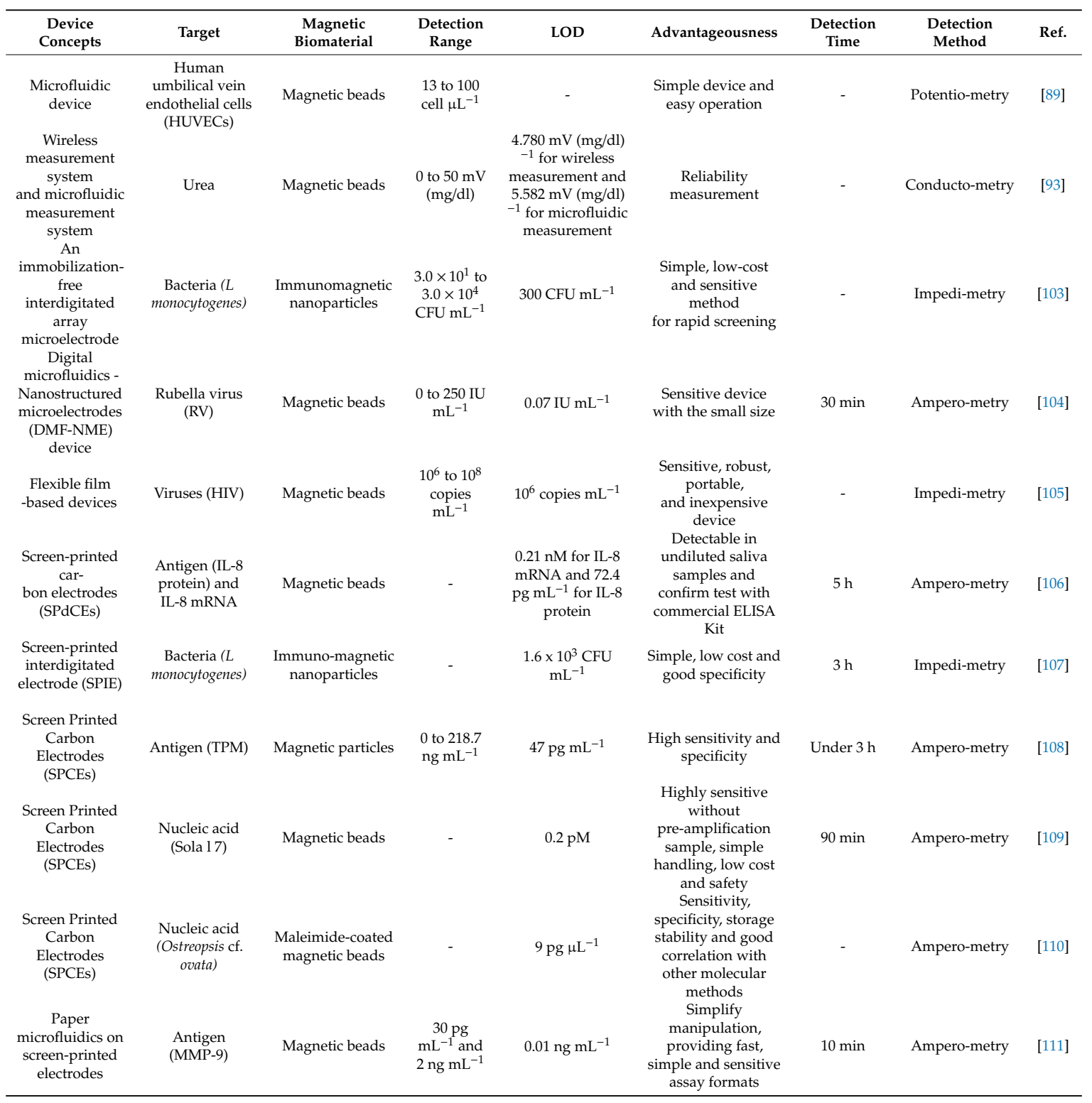

\section{Magnetic Phenomena-Based Bioassays}

In this section, we will discuss magnetic phenomena used in biosensing platforms. Magnetic materials are basically composed of metals, such as $\mathrm{Fe}, \mathrm{Co}$, or $\mathrm{Ni}$, or metal oxides. Since they provide various advantages, such as larger surface area, specific controllability through a magnetic field, and functional alterations through surface modifications, they are often used to fulfill requirements for developing advanced forms of biosensing as ways of separating and pre-treatment of samples 
or used as detection probes for enhancing measured signals. Moreover, magnetic particles have been employed in various magnetic phenomena-based bioassays. This review will categorize recent magnetic nanoparticle-based assays into giant magnetoresistance (GMR), magnetic tunnel junction (MTJ), magnetic particle spectroscopy (MPS), and the nuclear magnetic resonance (NMR)-based assay.

\subsection{GMR-Based Bioassay}

Giant magnetoresistance (GMR) biosensor employs the basic phenomenon that occurs in magnetic materials including nanoparticles, multilayered thin films, and permanent magnets combined with bioreceptors. This appears alteration of magnetization in so called "free-layer" which consists GMR sensor platform, leading to the change of the resistance of GMR sensors [112] The detection takes place through measuring the signal intensity, which would be proportional to number of nanoparticles bound to the unit area [113]. It has been demonstrated that GMR sensors show highly sensitive and real-time signal readout. Furthermore, they can be produced with low cost which will be advantageous for mass production. [114-116] Through surface modification of MNPs, this platform can be widely used for detection of several biological targets as shown in Figure 5A,B. [113,117-122].

\subsection{MTJ-Based Bioassay}

Magnetic tunnel junction (MTJ) sensors, also one of the magneto resistive sensors, often called as tunnel magnetoresistance (TMR) sensor require low magnetic field while still offering high sensitivity because they possess higher ratio of magnetoresistance compared with GMR. Furthermore, there are various important qualities of TMR sensor platform such as convenience, less demand of sample quantity, wider conditions for choices of working temperature and voltage [123,124]. Furthermore, this feature can lead to fabrication of power-saving sensors, strengthening the merits of producing economic and eco-friendly bioassay devices [125]. TMR is caused by spinning coming from electron tunneling. Several studies have done for detecting bio recognition elements. For instance, Xiao's team detected magnetic nanoparticles conjugated with DNA on MgO-based sensor surface [126]. To detect E. coli O157:H7 while using test strips, capture antibody-conjugated magnetic beads were employed. Signals were measured based on a potential change caused by difference of magnetic field fluctuation pattern due to the contrast between existence and absence of target binding to antibody-conjugated MNPs [127] (see Figure 5C,D). Mu et al. also conducted a study of detecting ricin on a test strip with magnetic field generating platform constituting of vertical and horizontal coils [128]. 

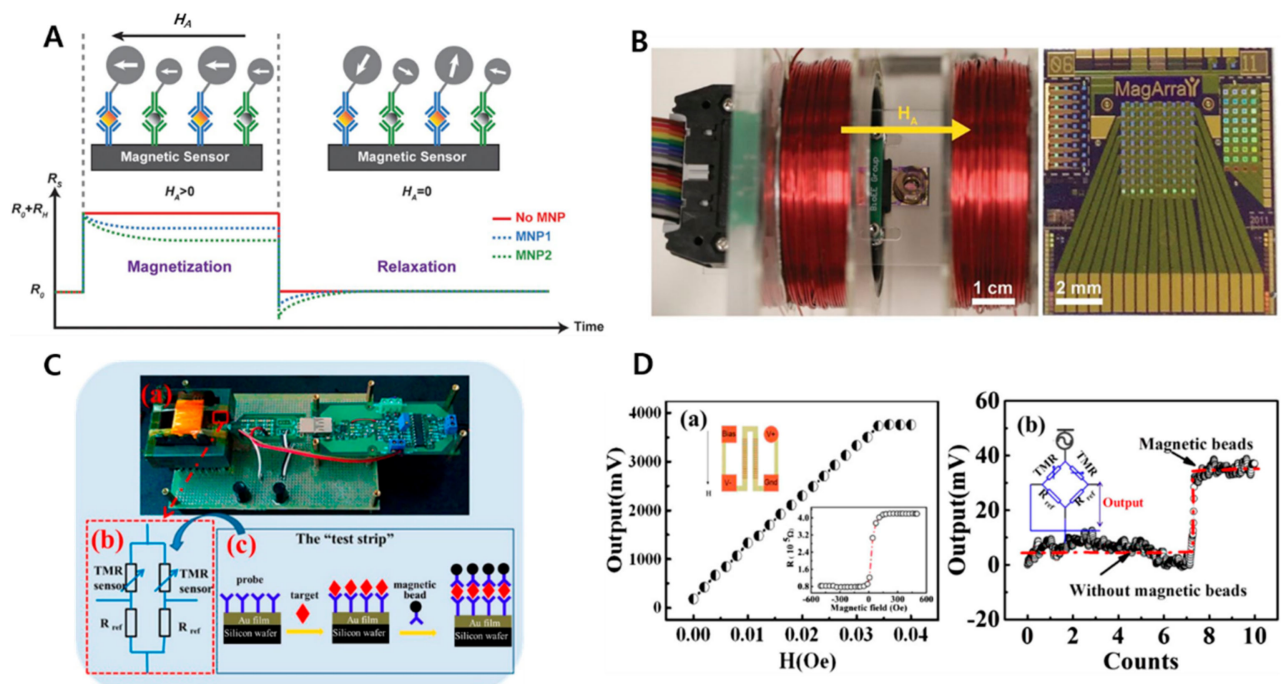

Figure 5. (A) Illustration of giant magnetoresistance (GMR) biosensors for time-domain magnetorelaxometry with the corresponding resistance signals in response to the external magnetic field; (B) simplified measurement setup with electromagnet and sensor array and GMR sensor array; (C) the Wheatstone bridge based on tunnel magnetoresistance (TMR) sensors and the sandwich assay on a test strip; (D) the results of the system under different magnetic fields, and the real-time response of the system when applying the magnetic beads. Inset: magnetic field dependence on the resistance of a TMR sensor. Reproduced with permission from [122,127].

\subsection{MPS-Based Bioassay}

Magnetic particle spectroscopy (MPS), also known as magnetization response spectroscopy, is a newly rising technique that applies a sinusoidal magnetic field applied to superparamagnetic iron oxide nanoparticles and observes their periodical saturation of magnetization in response to the magnetic field $[129,130]$. MPS signal is only observed from magnetic nanoparticles, rather than iron in blood or biological tissue, which makes it more accurate to quantify MNPs unaffected by other undesired factors [131]. Combined with Brownian relaxation methods, biotin-coated MNPs captured streptavidin successfully, which also showed sensitivity of detecting streptavidin at as low a concentration as 75nM. The demonstrated study adopted the changes in MPS patterns that occur when MNPs are bound to specific target, while diminishing the need of washing process [132].

\subsection{NMR-Based Bioassay}

Nuclear magnetic resonance is a physical event that occurs when a certain atomic nucleus is placed in magnetic field to absorb electromagnetic radiation and released again. Through numerous investigations of this event, one can apply this event to analyze the magnetic characteristics of nuclei and develop the information to detect bio-molecules as well [133]. Due to the facts that this signal can pass through samples without destructing them and sample preparation time is not necessary, NMR methods are adequate to analyze biological samples, and to save up time for analysis. With various modifications to improve this technique, fast and accurate detection with small sample volume has been made possible, also enabling mass production of handy-sized, easy-of-use sensor platform with low cost $[134,135]$. Addition of magnetic nanoparticles to the platforms can guarantee higher sensitivity and shorten the testing time. To detect prostate-specific antigen, nitrocellulose membrane-based test strips were designed and measured by a portable NMR relaxometer [136]. Many other research groups attempted to adopt this technique to detect several biological components such as food borne bacteria [137-140] (See Figure 6). 
A
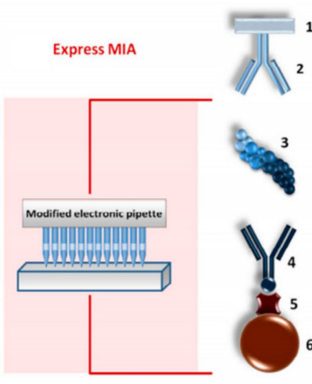

C

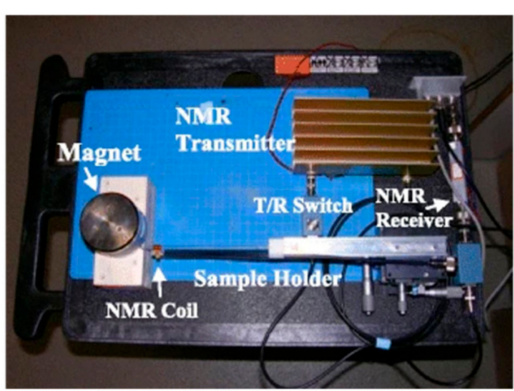

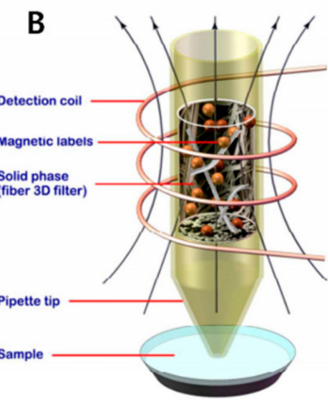
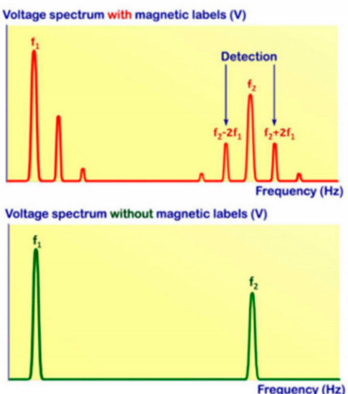

D

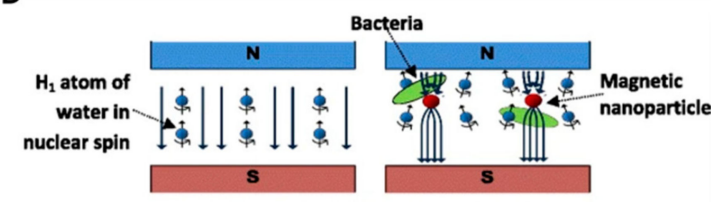

NMR Free Induction Decay Signal V.S. Time

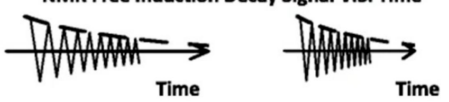

Figure 6. (A) Illustration of magnetic immunosandwich on 3D fiber filters used as a solid phase: 1- filter surface, 2-capture antibody, 3-antigen, 4-biotinylated tracer antibody, 5-streptavidin, 6-magnetic nanoparticles; (B) detection of superparamagnetic nanolabels by their non-linear response at combinatorial frequencies from the whole volume of 3D solid phase located inside a pipette tip; (C) portable nuclear magnetic resonance biosensor; (D) assay for the highly sensitive and rapid detection of foodborne bacteria in complex matrices. Reproduced with permission from $[130,134]$.

\section{Concluding Remarks and Future Perspectives}

Recent advances in magnetic particles have been focusing on employing various biomedical applications to achieve highly sensitive and rapid sensing performance. Magnetic particle-based target-molecule separation processes for sample preparation have been developed and reported by multiple research groups. For point-of-care biosensing devices, various magnetic particles were easily applied for the enhanced performances of biosensors with various techniques, such as the optical/electrochemical method combined with a microfluidic channel or LFA system, and also various magnetic phenomena-based bioassays, resulting in greatly simplifying extraction and detection procedures. In this review, the use of magnetic materials in the efficient isolations of various molecules and cells, and their successful use in many types of diagnostic biosensors, were summarized. These simple, rapid, and sensitive approaches may show promising developments in point-of-care and high-throughput biological devices for precise testing and analysis within a short time, greatly improving human health in the future.

Author Contributions: Conceptualization, M.-H.L. and S.-E.K.; methodology, S.-E.K.; validation, S.-E.K., M.V.T. and S.Y.H.; writing — original draft preparation, S.-E.K.; writing—review and editing, S.-E.K.; visualization, M.V.T. and S.Y.H.; supervision, M.-H.L.; funding acquisition, M.-H.L. All authors have read and agreed to the published version of the manuscript.

Funding: This study was financially supported by the Ministry of the Environment (grant number RQ201901136) and the National Research Foundation of Korea (NRF) grant funded by the Korean government (MSIT) (number NRF-2019R1F1A1060724).

Conflicts of Interest: The authors declare no conflict of interest.

\section{References}

1. Wu, W.; Wu, Z.; Yu, T.; Jiang, C.; Kim, W.S. Recent progress on magnetic iron oxide nanoparticles: Synthesis, surface functional strategies and biomedical applications. Sci. Technol. Adv. Mater. 2015, 16, 023501. [CrossRef] 
2. Mahdavi, M.; Ahmad, M.B.; Haron, M.J.; Namvar, F.; Nadi, B.; Rahman, M.Z.; Amin, J. Synthesis, surface modification and characterisation of biocompatible magnetic iron oxide nanoparticles for biomedical applications. Molecules 2013, 18, 7533-7548. [CrossRef]

3. Silva, S.M.; Tavallaie, R.; Sandiford, L.; Tilley, R.D.; Gooding, J.J. Gold coated magnetic nanoparticles: From preparation to surface modification for analytical and biomedical applications. Chem. Commun. 2016, 52, 7528-7540. [CrossRef]

4. Yang, H.M.; Park, C.W.; Ahn, T.; Jung, B.; Seo, B.K.; Park, J.H.; Kim, J.D. A direct surface modification of iron oxide nanoparticles with various poly (amino acids) for use as magnetic resonance probes. J. Colloid Interface Sci. 2013, 391, 158-167. [CrossRef]

5. Yang, P.; Xu, H.; Zhang, Z.; Yang, L.; Kuang, H.; Aguilar, Z.P. Surface modification affect the biodistribution and toxicity characteristics of iron oxide magnetic nanoparticles in rats. IET Nanobiotechnology 2018, 12, 562-568. [CrossRef]

6. Iravani, S. Bio-Based Synthesis of Magnetic Nanoparticles and Their Applications. In Magnetic Nanostructures: Environmental and Agricultural Applications; Abd-Elsalam, K.A., Mohamed, M.A., Prasad, R., Eds.; Springer International Publishing: Berlin, Germany, 2019; pp. 13-31.

7. Elrahman, A.A.A.; Mansour, F.R. Targeted magnetic iron oxide nanoparticles: Preparation, functionalization and biomedical application. J. Drug Deliv. Sci. Technol. 2019, 52, 702-712. [CrossRef]

8. Kotchoni, S.O.; Gachomo, E.W. A rapid and hazardous reagent free protocol for genomic DNA extraction suitable for genetic studies in plants. Mol. Boil. Rep. 2009, 36, 1633-1636. [CrossRef] [PubMed]

9. Yi, D.K.; Selvan, S.T.; Lee, S.S.; Papaefthymiou, G.C.; Kundaliya, D.; Ying, J.Y. Silica-coated nanocomposites of magnetic nanoparticles and quantum dots. J. Am. Chem. Soc. 2005, 127, 4990-4991. [CrossRef] [PubMed]

10. Elrefai, A.L.; Yoshida, T.; Enpuku, K. Magnetic parameters evaluation of magnetic nanoparticles for use in biomedical applications. J. Magn. Magn. Mater. 2019, 474, 522-527. [CrossRef]

11. Xianyu, Y.; Wang, Q.; Chen, Y. Magnetic particles-enabled biosensors for point-of-care testing. TrAC Trends Anal. Chem. 2018, 106, 213-224. [CrossRef]

12. Wu, K.; Su, D.; Liu, J.; Saha, R.; Wang, J.-P. Magnetic nanoparticles in nanomedicine: A review of recent advances. Nanotechnology 2019, 30, 502003. [CrossRef] [PubMed]

13. Vallabani, N.V.S.; Singh, S.; Karakoti, A.S. Magnetic Nanoparticles: Current Trends and Future Aspects in Diagnostics and Nanomedicine. Curr. Drug Metab. 2019, 20, 457-472. [CrossRef] [PubMed]

14. Ha, Y.; Ko, S.; Kim, I.; Huang, Y.; Mohanty, K.; Huh, C.; Maynard, J.A. Recent Advances Incorporating Superparamagnetic Nanoparticles into Immunoassays. ACS Appl. Nano Mater. 2018, 1, 512-521. [CrossRef] [PubMed]

15. Heidari, H.; Limouei-Khosrowshahi, B. Magnetic solid phase extraction with carbon-coated Fe3O4 nanoparticles coupled to HPLC-UV for the simultaneous determination of losartan, carvedilol, and amlodipine besylate in plasma samples. J. Chromatogr. B 2019, 1114, 24-30. [CrossRef] [PubMed]

16. Asgharinezhad, A.A.; Ebrahimzadeh, H.; Mirbabaei, F.; Mollazadeh, N.; Shekari, N. Dispersive micro-solid-phase extraction of benzodiazepines from biological fluids based on polyaniline/magnetic nanoparticles composite. Anal. Chim. Acta 2014, 844, 80-89. [CrossRef]

17. Feng, Z.; Yang, R.; Du, B. Fast SPE and HPLC-DAD determination of brucine in human urine using multi-walled carbon nanotubes modified with magnetic nanoparticles. J. Anal. Chem. 2017, 72, 862-869. [CrossRef]

18. Chen, L.; Zhang, M.; Fu, F.; Li, J.; Lin, Z. Facile synthesis of magnetic covalent organic framework nanobeads and application to magnetic solid-phase extraction of trace estrogens from human urine. J. Chromatogr. A 2018, 1567, 136-146. [CrossRef]

19. Mirzapour, H.; Panahi, H.A.P.A.; Moniri, E.M.; Feizbakhsh, A.F. Magnetic nanoparticles modified with organic dendrimers containing methyl methacrylate and ethylene diamine for the microextraction of rosuvastatin. Microchim. Acta 2018, 185, 440. [CrossRef]

20. Ji, W.-H.; Guo, Y.-S.; Wang, X.; Guo, D.-S. A water-compatible magnetic molecularly imprinted polymer for the selective extraction of risperidone and 9-hydroxyrisperidone from human urine. Talanta 2018, 181, 392-400. [CrossRef]

21. Zhang, R.; Wang, S.; Yang, Y.; Deng, Y.; Li, D.; Su, P.; Yang, Y. Modification of polydopamine-coated Fe3O4 nanoparticles with multi-walled carbon nanotubes for magnetic- $\mu$-dispersive solid-phase extraction of antiepileptic drugs in biological matrices. Anal. Bioanal. Chem. 2018, 410, 3779-3788. [CrossRef] 
22. Zhou, Z.; Kadam, U.; Irudayaraj, J. One-step Genome DNA extraction by Salicylic Acid Coated Magnetic Nanoparticles. Anal. Biochem. 2013, 442, 249-252. [CrossRef] [PubMed]

23. Saiyed, Z.M.; Ramchand, C.N.; Telang, S.D. Isolation of genomic DNA using magnetic nanoparticles as a solid-phase support. J. Physics: Condens. Matter 2008, 20, 204153. [CrossRef] [PubMed]

24. Shan, Z.; Zhou, Z.; Chen, H.; Zhang, Z.; Zhou, Y.; Wen, A.; Oakes, K.D.; Servos, M.R. PCR-ready human DNA extraction from urine samples using magnetic nanoparticles. J. Chromatogr. B 2012, 881, 63-68. [CrossRef] [PubMed]

25. Odabaşi, M.; Denizli, A.; Odabaşı, M. Polyhydroxyethylmethacrylate-based magnetic DNA-affinity beads for anti-DNA antibody removal from systemic lupus erythematosus patient plasma. J. Chromatogr. B 2001, 760, 137-148. [CrossRef]

26. Meng, Z.-H.; Lin, B.; Xie, Y.-H.; Zhang, K.-Q. Cloning and expression of fused Fc-binding protein (SPA-SPG) and its application in purification of IgG. Prog. Biochem. Biophys. 2004, 31, 146-149.

27. Bhagwati, S.; Ghatpande, A.; Leung, B. Identification of Two Nuclear Proteins Which Bind to RNA CUG Repeats: Significance for Myotonic Dystrophy. Biochem. Biophys. Res. Commun. 1996, 228, 55-62. [CrossRef]

28. Zollner, T.C.A.; Zollner, R.D.L.; De Cuyper, M.; Santana, M.H.A. Adsorption of Isotype "E” Antibodies on Affinity Magnetoliposomes. J. Dispers. Sci. Technol. 2003, 24, 615-622. [CrossRef]

29. Zeng, G.; Gao, L.; Xia, T.; Tencomnao, T.; Yu, R.K. Characterization of the 5 '-flanking fragment of the human GM3-synthase gene. Biochim. Biophys. Acta (BBA)-Gene Struct. Expr. 2003, 1625, 30-35. [CrossRef]

30. Blank, M.; Weinschenk, T.; Priemer, M.; Schluesener, H. Systematic evolution of a DNA aptamer binding to rat brain tumor microvessels selective targeting of endothelial regulatory protein pigpen. J. Biol. Chem. 2001, 276, 16464-16468. [CrossRef]

31. Chakraborty, A.; White, S.M.; Schaefer, T.S.; Ball, E.D.; Dyer, K.F.; Tweady, D.J. Granulocyte ColonyStimulating Factor Activation of Stat3alpha and Stat3beta in Immature Normal and Leukemic Human Myeloid Cells. Blood 1996, 88, 2442-2449. [CrossRef]

32. Müller-Schulte, D.; Brunner, H. Novel magnetic microspheres on the basis of poly (vinyl alcohol) as affinity medium for quantitative detection of glycated haemoglobin. J. Chromatogr. A 1995, 711, 53-60. [CrossRef]

33. Ji, Z.; Pinon, D.I.; Miller, L. Development of Magnetic Beads for Rapid and Efficient Metal-Chelate Affinity Purifications. Anal. Biochem. 1996, 240, 197-201. [CrossRef] [PubMed]

34. Lu, H.; Yi, G.; Zhao, S.; Chen, D.; Guo, L.-H.; Cheng, J. Synthesis and characterization of multi-functional nanoparticles possessing magnetic, up-conversion fluorescence and bio-affinity properties. J. Mater. Chem. 2004, 14, 1336. [CrossRef]

35. Tiikkaja, M.; Aro, A.L.; Alanko, T.; Lindholm, H.; Sistonen, H.; Hartikainen, J.E.; Toivonen, L.; Juutilainen, J.; Hietanen, M. Electromagnetic interference with cardiac pacemakers and implantable cardioverter-defibrillators from low-frequency electromagnetic fields in vivo. Europace 2013, 15, 388-394. [CrossRef] [PubMed]

36. Wang, C.; Yuan, H.; Duan, Z.; Xiao, D. Integrated multi-ISE arrays with improved sensitivity, accuracy and precision. Sci. Rep. 2017, 7, 44771. [CrossRef] [PubMed]

37. Nima, Z.A.; Watanabe, F.; Jamshidi-Parsian, A.; Sarimollaoglu, M.; Nedosekin, D.A.; Han, M.; Watts, J.A.; Biris, A.S.; Zharov, V.P.; Galanzha, E.I. Bioinspired magnetic nanoparticles as multimodal photoacoustic, photothermal and photomechanical contrast agents. Sci. Rep. 2019, 9, 887. [CrossRef]

38. Coleman, B.; Coarsey, C.; Asghar, W. Cell phone based colorimetric analysis for point-of-care settings. Analyst 2019, 144, 1935-1947. [CrossRef]

39. Kangas, M.J.; Burks, R.M.; Atwater, J.; Lukowicz, R.M.; Williams, P.; Holmes, A.E. Colorimetric Sensor Arrays for the Detection and Identification of Chemical Weapons and Explosives. Crit. Rev. Anal. Chem. 2017, 47, 138-153. [CrossRef]

40. Yetisen, A.K.; Akram, M.S.; Lowe, C.R. Paper-based microfluidic point-of-care diagnostic devices. Lab Chip 2013, 13, 2210-2251. [CrossRef]

41. Reboud, J.; Xu, G.; Garrett, A.; Adriko, M.; Yang, Z.; Tukahebwa, E.M.; Rowell, C.; Cooper, J. Paper-based microfluidics for DNA diagnostics of malaria in low resource underserved rural communities. Proc. Natl. Acad. Sci. 2019, 116, 4834-4842. [CrossRef]

42. Shin, J.; Choi, S.; Yang, J.-S.; Song, J.; Choi, J.-S.; Jung, H.-I. Smart Forensic Phone: Colorimetric analysis of a bloodstain for age estimation using a smartphone. Sensors Actuators B Chem. 2017, 243, 221-225. [CrossRef] 
43. Jung, Y.; Kim, J.; Awofeso, O.; Kim, H.; Regnier, F.; Bae, E. Smartphone-based colorimetric analysis for detection of saliva alcohol concentration. Appl. Opt. 2015, 54, 9183-9189. [CrossRef] [PubMed]

44. Srisa-Art, M.; Boehle, K.E.; Geiss, B.J.; Henry, C.S. Highly Sensitive Detection of Salmonella typhimurium Using a Colorimetric Paper-Based Analytical Device Coupled with Immunomagnetic Separation. Anal. Chem. 2018, 90, 1035-1043. [CrossRef] [PubMed]

45. Kim, M.S.; Kweon, S.H.; Cho, S.; An, S.S.A.; Kim, M.I.; Doh, J.; Lee, J. Pt-Decorated Magnetic Nanozymes for Facile and Sensitive Point-of-Care Bioassay. ACS Appl. Mater. Interfaces 2017, 9, 35133-35140. [CrossRef]

46. Wang, D.B.; Tian, B.; Zhang, Z.P.; Wang, X.Y.; Fleming, J.; Bi, L.J.; Yang, R.F.; Zhang, X.E. Detection of Bacillus anthracis spores by super-paramagnetic lateral-flow immunoassays based on "Road Closure". Biosens. Bioelectron. 2015, 67, 608-614. [CrossRef]

47. Suaifan, G.; Alhogail, S.; Zourob, M. Paper-based magnetic nanoparticle-peptide probe for rapid and quantitative colorimetric detection of Escherichia coli O157:H7. Biosens. Bioelectron. 2017, 92, 702-708. [CrossRef]

48. Guo, R.; Wang, S.; Huang, F.; Chen, Q.; Li, Y.; Liao, M.; Lin, J. Rapid detection of Salmonella Typhimurium using magnetic nanoparticle immunoseparation, nanocluster signal amplification and smartphone image analysis. Sensors Actuators B Chem. 2019, 284, 134-139. [CrossRef]

49. Huang, Y.; Wu, T.; Wang, F.; Li, K.; Qian, L.; Zhang, X.; Liu, G. Magnetized Carbon Nanotube Based Lateral Flow Immunoassay for Visual Detection of Complement Factor B. Molecules 2019, 24, 2759. [CrossRef]

50. Russell, S.M.; Alba-Patino, A.; Borges, M.; de la Rica, R. Multifunctional motion-to-color janus transducers for the rapid detection of sepsis biomarkers in whole blood. Biosens. Bioelectron. 2019, 140, 111346. [CrossRef]

51. Li, F.; Li, F.; Luo, D.; Lai, W.; Xiong, Y.; Xu, H. Biotin-exposure-based immunomagnetic separation coupled with nucleic acid lateral flow biosensor for visibly detecting viable Listeria monocytogenes. Anal. Chim. Acta 2018, 1017, 48-56. [CrossRef]

52. Quinn, M.K.; Gnan, N.; James, S.; Ninarello, A.; Sciortino, F.; Zaccarelli, E.; McManus, J.J. How fluorescent labelling alters the solution behaviour of proteins. Phys. Chem. Chem. Phys. 2015, 17, 31177-31187. [CrossRef] [PubMed]

53. Prendergast, F.G.; Mann, K.G. Chemical and physical properties of aequorin and the green fluorescent protein isolated from Aequorea forskalea. Biochemistry 1978, 17, 3448-3453. [CrossRef] [PubMed]

54. Zeng, Y.; Zhu, J.; Wang, J.; Parasuraman, P.; Busi, S.; Nauli, S.M.; Wang, Y.X.J.; Pala, R.; Liu, G. Functional probes for cardiovascular molecular imaging. Quant. Imaging Med. Surg. 2018, 8, 838-852. [CrossRef] [PubMed]

55. Kim, S.E.; Jo, S.D.; Kwon, K.C.; Won, Y.Y.; Lee, J. Genetic Assembly of Double-Layered Fluorescent Protein Nanoparticles for Cancer Targeting and Imaging. Adv. Sci. 2017, 4, 1600471. [CrossRef]

56. Lim, M.C.; Kim, Y.R. Analytical Applications of Nanomaterials in Monitoring Biological and Chemical Contaminants in Food. J. Microbiol. Biotechnol. 2016, 26, 1505-1516. [CrossRef]

57. Li, C. A targeted approach to cancer imaging and therapy. Nat. Mater. 2014, 13, 110-115. [CrossRef]

58. Reslova, N.; Michna, V.; Kasny, M.; Mikel, P.; Kralik, P. xMAP Technology: Applications in Detection of Pathogens. Front. Microbiol. 2017, 8, 55. [CrossRef]

59. Burnham, C.-A.D.; Doern, C.; Binder, S.R. Viral Diseases 1, The Immunoassay Handbook; Elsevier: Amsterdam, The Netherlands, 2013; pp. 919-927.

60. Doseeva, V.; Colpitts, T.; Gao, G.; Woodcock, J.; Knezevic, V. Performance of a multiplexed dual analyte immunoassay for the early detection of non-small cell lung cancer. J. Transl. Med. 2015, 13, 55. [CrossRef]

61. Breen, E.J.; Tan, W.; Khan, A. The Statistical Value of Raw Fluorescence Signal in Luminex xMAP Based Multiplex Immunoassays. Sci. Rep. 2016, 6, 26996. [CrossRef]

62. Verbarg, J.; Hadass, O.; Olivo, P.D.; Danielli, A. High sensitivity detection of a protein biomarker interleukin-8 utilizing a magnetic modulation biosensing system. Sensors Actuators B Chem. 2017, 241, 614-618. [CrossRef]

63. Chunyk, A.G.; Joyce, A.; Fischer, S.K.; Dysinger, M.; Mikulskis, A.; Jeromin, A.; Lawrence-Henderson, R.; Baker, D.; Yeung, D. A Multi-site In-depth Evaluation of the Quanterix Simoa from a User's Perspective. AAPS J. 2017, 20, 10. [CrossRef] [PubMed]

64. Poorbaugh, J.; Samanta, T.; Bright, S.W.; Sissons, S.E.; Chang, C.Y.; Oberoi, P.; MacDonald, A.J.; Martin, A.P.; Cox, K.L.; Benschop, R.J. Measurement of IL-21 in human serum and plasma using ultrasensitive MSD S-PLEX(R) and Quanterix SiMoA methodologies. J. Immunol. Methods 2019, 466, 9-16. [CrossRef] [PubMed] 
65. Anker, J.N.; Behrend, C.J.; Huang, H.; Kopelman, R. Magnetically-modulated optical nanoprobes (MagMOONs) and systems. J. Magn. Magn. Mater. 2005, 293, 655-662. [CrossRef]

66. Nguyen, K.T.; Anker, J.N. Detecting De-gelation through Tissue Using Magnetically Modulated Optical Nanoprobes (MagMOONs). Sensors Actuators B Chem. 2014, 205, 313-321. [CrossRef]

67. Wang, S.; Zheng, L.; Cai, G.; Liu, N.; Liao, M.; Li, Y.; Zhang, X.; Lin, J. A microfluidic biosensor for online and sensitive detection of Salmonella typhimurium using fluorescence labeling and smartphone video processing. Biosens. Bioelectron. 2019, 140, 111333. [CrossRef]

68. Zhang, Y.; Zhang, L.; Yang, L.; Vong, C.I.; Chan, K.-F.; Wu, W.K.K.; Kwong, T.N.Y.; Lo, N.W.; Ip, M.; Wong, S.H.; et al. Real-time tracking of fluorescent magnetic spore-based microrobots for remote detection of C. diff toxins. Sci. Adv. 2019, 5, eaau9650. [CrossRef]

69. Burg, S.; Cohen, M.; Margulis, M.; Roth, S.; Danielli, A. Magnetically aggregated biosensors for sensitive detection of biomarkers at low concentrations. Appl. Phys. Lett. 2019, 115, 103702. [CrossRef]

70. Zeng, S.; Baillargeat, D.; Ho, H.P.; Yong, K.T. Nanomaterials enhanced surface plasmon resonance for biological and chemical sensing applications. Chem. Soc. Rev. 2014, 43, 3426-3452. [CrossRef]

71. Zhou, X.; Li, X.; Li, S.; An, G.-W.; Cheng, T. Magnetic Field Sensing Based on SPR Optical Fiber Sensor Interacting With Magnetic Fluid. IEEE Trans. Instrum. Meas. 2019, 68, 234-239. [CrossRef]

72. Jiang, J.; Wang, X.; Li, S.; Ding, F.; Li, N.; Meng, S.; Li, R.; Qi, J.; Liu, Q.; Liu, G.L. Plasmonic nano-arrays for ultrasensitive bio-sensing. Nanophotonics 2018, 7, 1517-1531. [CrossRef]

73. Reiner, A.T.; Fossati, S.; Dostalek, J. Biosensor platform for parallel surface plasmon-enhanced epifluorescence and surface plasmon resonance detection. Sensors Actuators B Chem. 2018, 257, 594-601. [CrossRef]

74. Liu, Y.; Liu, Q.; Chen, S.; Cheng, F.; Wang, H.; Peng, W. Surface Plasmon Resonance Biosensor Based on Smart Phone Platforms. Sci. Rep. 2015, 5, 12864. [CrossRef] [PubMed]

75. Pang, Y.; Wan, N.; Shi, L.; Wang, C.; Sun, Z.; Xiao, R.; Wang, S. Dual-recognition surface-enhanced Raman scattering(SERS)biosensor for pathogenic bacteria detection by using vancomycin-SERS tags and aptamer- $\mathrm{Fe}_{3} \mathrm{O}_{4} @$ Au. Anal. Chim. Acta 2019, 1077, 288-296. [CrossRef] [PubMed]

76. Ilkhani, H.; Hughes, T.; Li, J.; Zhong, C.J.; Hepel, M. Nanostructured SERS-electrochemical biosensors for testing of anticancer drug interactions with DNA. Biosens. Bioelectron. 2016, 80, 257-264. [CrossRef]

77. Fleischmann, M.; Hendra, P.J.; McQuillan, A.J. Raman spectra of pyridine adsorbed at a silver electrode. Chem. Phys. Lett. 1974, 26, 163-166. [CrossRef]

78. Xiong, Q.; Lim, C.Y.; Ren, J.; Zhou, J.; Pu, K.; Chan-Park, M.B.; Mao, H.; Lam, Y.C.; Duan, H. Magnetic nanochain integrated microfluidic biochips. Nat. Commun. 2018, 9, 1743. [CrossRef]

79. Zhang, H.; Ma, X.; Liu, Y.; Duan, N.; Wu, S.; Wang, Z.; Xu, B. Gold nanoparticles enhanced SERS aptasensor for the simultaneous detection of Salmonella typhimurium and Staphylococcus aureus. Biosens. Bioelectron. 2015, 74, 872-877. [CrossRef]

80. Mohammadniaei, M.; Nguyen, H.V.; Tieu, M.V.; Lee, M.H. 2D Materials in Development of Electrochemical Point-of-Care Cancer Screening Devices. Micromachines 2019, 10, 662. [CrossRef]

81. Wu, H.; Gao, W.; Yin, Z. Materials, Devices and Systems of Soft Bioelectronics for Precision Therapy. Adv. Healthc. Mater. 2017, 6, 1700017. [CrossRef]

82. Bandodkar, A.J.; Mohan, V.; López, C.S.; Ramírez, J.; Wang, J. Self-Healing Inks for Autonomous Repair of Printable Electrochemical Devices. Adv. Electron. Mater. 2015, 1, 1500289. [CrossRef]

83. Sempionatto, J.R.; Martin, A.; García-Carmona, L.; Barfidokht, A.; Kurniawan, J.F.; Moreto, J.R.; Tang, G.; Shin, A.; Liu, X.; Escarpa, A.; et al. Skin-worn Soft Microfluidic Potentiometric Detection System. Electroanalysis 2019, 31, 239-245. [CrossRef]

84. Dobbelaere, T.; Vereecken, P.M.; Detavernier, C. A USB-controlled potentiostat/galvanostat for thin-film battery characterization. HardwareX 2017, 2, 34-49. [CrossRef]

85. Guilbault, G.G.; Montalvo, J.G. Urea-specific enzyme electrode. J. Am. Chem. Soc. 1969, 91, $2164-2165$. [CrossRef]

86. Liu, C.; Neale, Z.G.; Cao, G. Understanding electrochemical potentials of cathode materials in rechargeable batteries. Mater. Today 2016, 19, 109-123. [CrossRef]

87. Ainla, A.; Mousavi, M.P.S.; Tsaloglou, M.N.; Redston, J.; Bell, J.G.; Fernandez-Abedul, M.T.; Whitesides, G.M. Open-Source Potentiostat for Wireless Electrochemical Detection with Smartphones. Anal. Chem. 2018, 90, 6240-6246. [CrossRef] 
88. Canovas, R.; Parrilla, M.; Blondeau, P.; Andrade, F.J. A novel wireless paper-based potentiometric platform for monitoring glucose in blood. Lab Chip 2017, 17, 2500-2507. [CrossRef]

89. Liu, F.; Kc, P.; Zhang, G.; Zhe, J. In situ single cell detection via microfluidic magnetic bead assay. PLoS ONE 2017, 12, e0172697. [CrossRef]

90. Dzyadevych, S.; Jaffrezic-Renault, N. Conductometric biosensors. Biological Identification 2014, 6, $153-193$.

91. Soldatkin, O.O.; Burdak, O.S.; Sergeyeva, T.A.; Arkhypova, V.M.; Dzyadevych, S.V.; Soldatkin, A.P. Acetylcholinesterase-based conductometric biosensor for determination of aflatoxin B1. Sensors Actuators $B$ Chem. 2013, 188, 999-1003. [CrossRef]

92. Saiapina, O.Y.; Pyeshkova, V.M.; Soldatkin, O.O.; Melnik, V.G.; Kurç, B.A.; Walcarius, A.; Dzyadevych, S.V.; Jaffrezic-Renault, N. Conductometric enzyme biosensors based on natural zeolite clinoptilolite for urea determination. Mater. Sci. Eng. C 2011, 31, 1490-1497. [CrossRef]

93. Chou, J.C.; Wu, C.Y.; Lin, S.H.; Kuo, P.Y.; Lai, C.H.; Nien, Y.H.; Wu, Y.X.; Lai, T.Y. The Analysis of the Urea Biosensors Using Different Sensing Matrices via Wireless Measurement System \& Microfluidic Measurement System. Sensors 2019, 19, 3004.

94. Tieu, M.V.; Go, A.; Park, Y.J.; Nguyen, H.V.; Hwang, S.Y.; Lee, M.-H. Highly Sensitive ELISA Using Membrane-Based Microwave-Mediated Electrochemical Immunoassay for Thyroid-Stimulating Hormone Detection. IEEE Sensors J. 2019, 19, 9826-9831. [CrossRef]

95. Mistry, K.K.; Layek, K.; Chell, T.N.; Chaudhuri, C.R.; Saha, H. Design and development of an amperometric immunosensor based on screen-printed electrodes. Anal. Methods 2016, 8, 3096-3101. [CrossRef]

96. Bandodkar, A.J.; López, C.S.; Mohan, A.M.V.; Yin, L.; Kumar, R.; Wang, J. All-printed magnetically self-healing electrochemical devices. Sci. Adv. 2016, 2, e1601465. [CrossRef] [PubMed]

97. Ducote, M.; Vinson, B.; Hogquist, S. Electrochemical Impedance Spectroscopy (EIS) as a Tool for Pathogen Detection. J. Biosens. Bioelectron. 2016, 7, 224.

98. Baleg, A.A.; Jahed, N.; Yonkeu, A.L.D.; Njomo, N.; Mbambisa, G.; Molapo, K.M.; Fuku, X.G.; Fomo, G.; Makelane, H.; Tsegaye, A.; et al. Impedimetry and microscopy of electrosynthetic poly (propylene imine)-co-polypyrrole conducting dendrimeric star copolymers. Electrochimica Acta 2014, 128, 448-457. [CrossRef]

99. Yagati, A.K.; Chavan, S.G.; Baek, C.; Lee, M.H.; Min, J. Label-Free Impedance Sensing of Aflatoxin B(1) with Polyaniline Nanofibers/Au Nanoparticle Electrode Array. Sensors 2018, 18, 1320. [CrossRef]

100. Spain, E.; Carrara, S.; Adamson, K.; Ma, H.; O’Kennedy, R.; de Cola, L.; Forster, R.J. Cardiac Troponin I: Ultrasensitive Detection Using Faradaic Electrochemical Impedance. ACS Omega 2018, 3, 17116-17124. [CrossRef]

101. Wang, Y.; Ye, Z.; Ping, J.; Jing, S.; Ying, Y. Development of an aptamer-based impedimetric bioassay using microfluidic system and magnetic separation for protein detection. Biosens. Bioelectron. 2014, 59, 106-111. [CrossRef]

102. Kongsuphol, P.; Ng, H.H.; Pursey, J.P.; Arya, S.K.; Wong, C.C.; Stulz, E.; Park, M.K. EIS-based biosensor for ultra-sensitive detection of TNF-alpha from non-diluted human serum. Biosens. Bioelectron. 2014, 61, 274-279. [CrossRef]

103. Chen, Q.; Lin, J.; Gan, C.; Wang, Y.; Wang, D.; Xiong, Y.; Lai, W.; Li, Y.; Wang, M. A sensitive impedance biosensor based on immunomagnetic separation and urease catalysis for rapid detection of Listeria monocytogenes using an immobilization-free interdigitated array microelectrode. Biosens. Bioelectron. 2015, 74, 504-511. [CrossRef] [PubMed]

104. Rackus, D.G.; Dryden, M.D.; Lamanna, J.; Zaragoza, A.; Lam, B.; Kelley, S.O.; Wheeler, A.R. A digital microfluidic device with integrated nanostructured microelectrodes for electrochemical immunoassays. Lab Chip 2015, 15, 3776-3784. [CrossRef] [PubMed]

105. Shafiee, H.; Asghar, W.; Inci, F.; Yuksekkaya, M.; Jahangir, M.; Zhang, M.H.; Durmus, N.G.; Gurkan, U.A.; Kuritzkes, D.R.; Demirci, U. Paper and flexible substrates as materials for biosensing platforms to detect multiple biotargets. Sci. Rep. 2015, 5, 8719. [CrossRef] [PubMed]

106. Torrente-Rodriguez, R.M.; Campuzano, S.; Montiel, V.R.; Gamella, M.; Pingarron, J.M. Electrochemical bioplatforms for the simultaneous determination of interleukin (IL)-8 mRNA and IL-8 protein oral cancer biomarkers in raw saliva. Biosens. Bioelectron. 2016, 77, 543-548. [CrossRef] 
107. Wang, D.; Chen, Q.; Huo, H.; Bai, S.; Cai, G.; Lai, W.; Lin, J. Efficient separation and quantitative detection of Listeria monocytogenes based on screen-printed interdigitated electrode, urease and magnetic nanoparticles. Food Control. 2017, 73, 555-561. [CrossRef]

108. Angulo-Ibanez, A.; Eletxigerra, U.; Lasheras, X.; Campuzano, S.; Merino, S. Electrochemical tropomyosin allergen immunosensor for complex food matrix analysis. Anal. Chim. Acta 2019, 1079, 94-102. [CrossRef]

109. Pereira-Barros, M.A.; Barroso, M.F.; Martin-Pedraza, L.; Vargas, E.; Benede, S.; Villalba, M.; Rocha, J.M.; Campuzano, S.; Pingarron, J.M. Direct PCR-free electrochemical biosensing of plant-food derived nucleic acids in genomic DNA extracts. Application to the determination of the key allergen Sola 17 in tomato seeds. Biosens. Bioelectron. 2019, 137, 171-177. [CrossRef]

110. Toldra, A.; Alcaraz, C.; Diogene, J.; O'Sullivan, C.K.; Campas, M. Detection of Ostreopsis cf. ovata in environmental samples using an electrochemical DNA-based biosensor. Sci. Total. Environ. 2019, 689, 655-661. [CrossRef]

111. Ruiz-Vega, G.; Garcia-Berrocoso, T.; Montaner, J.; Baldrich, E. Paper microfluidics on screen-printed electrodes for simple electrochemical magneto-immunosensor performance. Sensors Actuators B: Chem. 2019, $298,298$. [CrossRef]

112. Binasch, G.; Grünberg, P.; Saurenbach, F.; Zinn, W. Enhanced magnetoresistance in layered magnetic structures with antiferromagnetic interlayer exchange. Phys. Rev. B 1989, 39, 4828-4830. [CrossRef]

113. Krishna, V.D.; Wu, K.; Perez, A.M.; Wang, J.-P. Giant Magnetoresistance-based Biosensor for Detection of Influenza A Virus. Front. Microbiol. 2016, 7, 156. [CrossRef] [PubMed]

114. Wang, W.; Wang, Y.; Tu, L.; Feng, Y.; Klein, T.; Wang, J.-P. Magnetoresistive performance and comparison of supermagnetic nanoparticles on giant magnetoresistive sensor-based detection system. Sci. Rep. 2014, 4, 5716. [CrossRef] [PubMed]

115. Hall, D.A.; Gaster, R.S.; Lin, T.; Osterfeld, S.J.; Han, S.; Murmann, B.; Wang, S.X. GMR biosensor arrays: A system perspective. Biosens. Bioelectron. 2010, 25, 2051-2057. [CrossRef]

116. Qiu, W.; Chang, L.; Liang, Y.-C.; Litvinov, J.; Guo, J.; Chen, Y.-T.; Vu, B.; Kourentzi, K.; Xu, S.; Lee, T.R.; et al. Spin-Valve based magnetoresistive nanoparticle detector for applications in biosensing. Sensors Actuators A Phys. 2017, 265, 174-180. [CrossRef]

117. Wu, K.; Klein, T.; Krishna, V.D.; Su, D.; Perez, A.M.; Wang, J.-P. Portable GMR Handheld Platform for the Detection of Influenza A Virus. ACS Sensors 2017, 2, 1594-1601. [CrossRef] [PubMed]

118. Gupta, S.; Kakkar, V. DARPin based GMR Biosensor for the detection of ESAT-6 Tuberculosis Protein. Tuberculosis 2019, 118, 101852. [CrossRef] [PubMed]

119. Zhu, F.; Li, D.; Ding, Q.; Lei, C.; Ren, L.; Ding, X.; Sun, X. 2D magnetic MoS2-Fe3O4 hybrid nanostructures for ultrasensitive exosome detection in GMR sensor. Biosens. Bioelectron. 2020, 147, 111787. [CrossRef]

120. Klein, T.; Wang, W.; Yu, L.; Wu, K.; Boylan, K.L.M.; Vogel, R.I.; Skubitz, A.P.N.; Wang, J.-P. Development of a multiplexed giant magnetoresistive biosensor array prototype to quantify ovarian cancer biomarkers. Biosens. Bioelectron. 2019, 126, 301-307. [CrossRef]

121. Gao, Y.; Huo, W.; Zhang, L.; Lian, J.; Tao, W.; Song, C.; Tang, J.; Shi, S.; Gao, Y. Multiplex measurement of twelve tumor markers using a GMR multi-biomarker immunoassay biosensor. Biosens. Bioelectron. 2019, 123, 204-210. [CrossRef]

122. Huang, C.-C.; Zhou, X.; Hall, D.A. Giant Magnetoresistive Biosensors for Time-Domain Magnetorelaxometry: A Theoretical Investigation and Progress Toward an Immunoassay. Sci. Rep. 2017, 7, 45493. [CrossRef]

123. Yuasa, S.; Nagahama, T.; Fukushima, A.; Suzuki, Y.; Ando, K. Giant room-temperature magnetoresistance in single-crystal Fe/MgO/Fe magnetic tunnel junctions. Nat. Mater. 2004, 3, 868-871. [CrossRef] [PubMed]

124. Parkin, S.S.P.; Kaiser, C.; Panchula, A.; Rice, P.M.; Hughes, B.; Samant, M.; Yang, S.-H. Giant tunnelling magnetoresistance at room temperature with $\mathrm{MgO}(100)$ tunnel barriers. Nat. Mater. 2004, 3, 862-867. [CrossRef] [PubMed]

125. Negulescu, B.; Lacour, D.; Montaigne, F.; Gerken, A.; Paul, J.; Spetter, V.; Marien, J.; Duret, C.; Hehn, M. Wide range and tunable linear magnetic tunnel junction sensor using two exchange pinned electrodes. Appl. Phys. Lett. 2009, 95, 112502. [CrossRef]

126. Shen, W.; Schrag, B.D.; Carter, M.J.; Xie, J.; Xu, C.; Sun, S.; Xiao, G. Detection of DNA labeled with magnetic nanoparticles using MgO-based magnetic tunnel junction sensors. J. Appl. Phys. 2008, 103, 07A306. [CrossRef] 
127. Wu, Y.; Liu, Y.; Zhan, Q.; Liu, J.P.; Li, R.-W. Rapid detection of Escherichia coli O157:H7 using tunneling magnetoresistance biosensor. AIP Adv. 2017, 7, 056658. [CrossRef]

128. Mu, X.-H.; Liu, H.-F.; Tong, Z.-Y.; Du, B.; Liu, S.; Liu, B.; Liu, Z.-W.; Gao, C.; Wang, J.; Dong, H. A new rapid detection method for ricin based on tunneling magnetoresistance biosensor. Sensors Actuators B Chem. 2019, 284, 638-649. [CrossRef]

129. Wu, K.; Su, D.; Saha, R.; Wong, D.; Wang, J.-P. Magnetic particle spectroscopy-based bioassays: Methods, applications, advances, and future opportunities. J. Phys. D Appl. Phys. 2019, 52, 173001. [CrossRef]

130. Orlov, A.V.; Khodakova, J.A.; Nikitin, M.P.; Shepelyakovskaya, A.O.; Brovko, F.A.; Laman, A.G.; Grishin, E.V.; Nikitin, P.I. Magnetic Immunoassay for Detection of Staphylococcal Toxins in Complex Media. Anal. Chem. 2013, 85, 1154-1163. [CrossRef]

131. Biederer, S.; Knopp, T.; Sattel, T.F.; Lüdtke-Buzug, K.; Gleich, B.; Weizenecker, J.; Borgert, J.; Buzug, T.M. Magnetization response spectroscopy of superparamagnetic nanoparticles for magnetic particle imaging. $J$. Phys. D Appl. Phys. 2009, 42, 205007. [CrossRef]

132. Wu, K.; Liu, J.; Su, D.; Saha, R.; Wang, J.-P. Magnetic Nanoparticle Relaxation Dynamics-Based Magnetic Particle Spectroscopy for Rapid and Wash-Free Molecular Sensing. ACS Appl. Mater. Interfaces 2019, 11, 22979-22986. [CrossRef]

133. Zohra, I.; Fauzi, A.; Jawad, M. Uses of Nuclear Magnetic Resonance Spectroscopy Technique in Pharmaceutical Analysis: A Review. Int. J. Curr. Pharm. Rev. Res. 2017, 8, 79-84. [CrossRef]

134. Luo, Y.; Alocilja, E.C. Portable nuclear magnetic resonance biosensor and assay for a highly sensitive and rapid detection of foodborne bacteria in complex matrices. J. Boil. Eng. 2017, 11, 14. [CrossRef] [PubMed]

135. Hash, S.; Martinez-Viedma, M.P.; Fung, F.; Han, J.E.; Yang, P.; Wong, C.; Doraisamy, L.; Menon, S.; Lightner, D. Nuclear magnetic resonance biosensor for rapid detection of Vibrio parahaemolyticus. Biomed. J. 2019, 42, 187-192. [CrossRef] [PubMed]

136. Khramtsov, P.; Kropaneva, M.; Bochkova, M.; Timganova, V.; Zamorina, S.; Rayev, M. Solid-phase nuclear magnetic resonance immunoassay for the prostate-specific antigen by using protein-coated magnetic nanoparticles. Microchim. Acta 2019, 186, 768. [CrossRef] [PubMed]

137. Zhao, Y.; Li, Y.; Jiang, K.; Wang, J.; White, W.L.; Yang, S.; Lu, J. Rapid detection of Listeria monocytogenes in food by biofunctionalized magnetic nanoparticle based on nuclear magnetic resonance. Food Control. 2017, 71, 110-116. [CrossRef]

138. Huber, S.; Min, C.; Staat, C.; Oh, J.; Castro, C.M.; Haase, A.; Weissleder, R.; Gleich, B.; Lee, H. Multichannel digital heteronuclear magnetic resonance biosensor. Biosens. Bioelectron. 2019, 126, 240-248. [CrossRef]

139. Zou, D.; Jin, L.; Wu, B.; Hu, L.; Chen, X.; Huang, G.; Zhang, J. Rapid detection of Salmonella in milk by biofunctionalised magnetic nanoparticle cluster sensor based on nuclear magnetic resonance. Int. Dairy J. 2019, 91, 82-88. [CrossRef]

140. Wu, B.; Yang, T.; Zou, D.; Jin, L.; Liang, X.; Li, T.; Huang, G.; Zhang, J. Nuclear magnetic resonance biosensor based on streptavidin-biotin system and poly-l-lysine macromolecular targeted gadolinium probe for rapid detection of Salmonella in milk. Int. Dairy J. 2020, 102, 104594. [CrossRef]

(C) 2020 by the authors. Licensee MDPI, Basel, Switzerland. This article is an open access article distributed under the terms and conditions of the Creative Commons Attribution (CC BY) license (http://creativecommons.org/licenses/by/4.0/). 